\title{
THE
}

\section{Atmospheric sampling of Supertyphoon Mireille with NASA DC-8 aircraft on September 27, 1991, during PEM-West A}

\author{
RE. Newell \\ Brian G. Heikes \\ University of Rhode Island, bheikes@uri.edu \\ John Merrill \\ University of Rhode Island, jmerrill@uri.edu \\ et al
}

Follow this and additional works at: https://digitalcommons.uri.edu/gsofacpubs

Terms of Use

All rights reserved under copyright.

\section{Citation/Publisher Attribution}

Newell, R. E., et al. (1996), Atmospheric sampling of Supertyphoon Mireille with NASA DC-8 aircraft on September 27,1991, during PEM-West A, J. Geophys. Res., 101(D1), 1853-1871, doi: 10.1029/ 95JD01374.

Available at: https://doi.org/10.1029/95JD01374

This Article is brought to you for free and open access by the Graduate School of Oceanography at DigitalCommons@URI. It has been accepted for inclusion in Graduate School of Oceanography Faculty Publications by an authorized administrator of DigitalCommons@URI. For more information, please contact digitalcommons-group@uri.edu. 


\title{
Atmospheric sampling of Supertyphoon Mireille with NASA DC-8 aircraft on September 27, 1991, during PEM-West A
}

\author{
R. E. Newell, ${ }^{1}$ W. Hu, ${ }^{1}$ Z-X. Wu, ${ }^{1}$ Y. Zhu, ${ }^{1}$ H. Akimoto, ${ }^{2}$ B. E. Anderson, ${ }^{3}$ \\ E. V. Browell, ${ }^{3}$ G. L. Gregory, ${ }^{3}$ G. W. Sachse, ${ }^{3}$ M. C. Shipham, ${ }^{3}$ \\ A. S. Bachmeier, ${ }^{4}$ A.R. Bandy, ${ }^{5}$ D. C. Thornton, ${ }^{5}$ D. R. Blake, ${ }^{6}$ F. S. Rowland, ${ }^{6}$ \\ J. D. Bradshaw, ${ }^{7}$ J. H. Crawford ${ }^{7}$ D. D. Davis, ${ }^{7}$ S. T. Sandholm, ${ }^{7}$ W. Brockett, 8 \\ L. DeGreef, ${ }^{8}$ D. Lewis, ${ }^{8}$ D. McCormick, ${ }^{8}$ E. Monitz, ${ }^{8}$ J. E. Collins Jr., 9 \\ B. G. Heikes, ${ }^{10}$ J. T. Merrill, ${ }^{10}$ K. K. Kelly, ${ }^{11}$ S. C. Liu, ${ }^{11}$ Y. Kondo, ${ }^{12}$ \\ M. Koike, ${ }^{12}$ C.-M. Liu, ${ }^{13}$ F. Sakamaki, ${ }^{14}$ H. B. Singh, ${ }^{15}$ J. E . Dibb, ${ }^{16}$ \\ and R. W. Talbot ${ }^{16}$
}

\begin{abstract}
The DC-8 mission of September 27, 1991, was designed to sample air flowing into Typhoon Mireille in the boundary layer, air in the upper tropospheric eye region, and air emerging from the typhoon and ahead of the system, also in the upper troposphere. The objective was to find how a typhoon redistributes trace constituents in the West Pacific region and whether any such redistribution is important on the global scale. The boundary layer air $(300 \mathrm{~m})$, in a region to the $\mathrm{SE}$ of the eye, contained low mixing ratios of the tracer species $\mathrm{O}_{3}, \mathrm{CO}, \mathrm{C}_{2} \mathrm{H}_{6}, \mathrm{C}_{2} \mathrm{H}_{2}, \mathrm{C}_{3} \mathrm{H}_{8}, \mathrm{C}_{6} \mathrm{H}_{6}$ and $\mathrm{CS}_{2}$ but high values of dimethylsulfide (DMS). The eye region relative to the boundary layer, showed somewhat elevated levels of $\mathrm{CO}$, substantially increased levels of $\mathrm{O}_{3}, \mathrm{CS}_{2}$ and all nonmethane hydrocarbons (NMHCs), and somewhat reduced levels of DMS. Ahead of the eye, CO and the NMHCs remained unchanged, $\mathrm{O}_{3}$ and $\mathrm{CS}_{2}$ showed a modest decrease, and DMS showed a substantial decrease. There was no evidence from lidar cross sections of ozone for the downward entrainment of stratospheric air into the eye region; these sections show that low ozone values were measured in the troposphere. The DMS data suggest substantial entrainment of boundary layer air into the system, particularly into the eye wall region. Estimates of the DMS sulphur flux between the boundary layer and the free troposphere, based on computations of velocity potential and divergent winds, gave values of about $69 \mu \mathrm{g} \mathrm{S} \mathrm{m}^{-2} \mathrm{~d}^{-1}$ averaged over a $17.5^{\circ}$ grid square encompassing the typhoon. A few hours after sampling with the DC-8, Mireille passed over Oki Island, just to the north of Japan, producing surface values of ozone of $5.5 \mathrm{ppbv}$. These $\mathrm{O}_{3}$ levels are consistent with the low tropospheric values found by lidar and are more typical of equatorial regions. We suggest that the central eye region may act like a Taylor column which has moved poleward from low latitudes. The high-altitude photochemical environment within Typhoon Mireille was found to be quite active as evidenced by significant levels of measured gas phase $\mathrm{H}_{2} \mathrm{O}_{2}$ and $\mathrm{CH}_{3} \mathrm{OOH}$ and model-computed levels of $\mathrm{OH}$.
\end{abstract}

\footnotetext{
${ }^{1}$ Massachusetts Institute of Technology, Cambridge.

${ }^{2}$ University of Tokyo, Japan.

${ }^{3}$ NASA Langley Research Center, Hampton, Virginia.

${ }^{4}$ Lockheed Engineering and Sciences, Co., Hampton, Virginia.

5 Drexel University, Philadelphia, Pennsylvania.

${ }^{6}$ University of Califomia, Irvine.

${ }^{7}$ Georgia Institute of Technology, Atlanta.

${ }^{8}$ Ames Science and Applications Aircraft Division, NASA Ames Research Center, Moffett Field, California.
}

Copyright 1996 by the American Geophysical Union.

Paper number 95JD01374.

0148-0227/96/95JD-01374\$05.00
${ }^{9}$ Science and Technology Corp., Hampton, Virginia.

${ }^{10}$ University of Rhode Island, Kingston.

${ }^{11}$ NOAA Aeronomy Laboratory, Boulder, Colorado.

12 Nagoya University, Nagoya, Japan.

${ }^{13}$ National Taiwan University, Taipei.

${ }^{14}$ National Institute for Environmental Studies, Tsukuba, Japan

${ }^{15}$ NASA Ames Research Center, Moffett Field, Califomia.

${ }^{16}$ University of New Hampshire, Durham.

\section{Introduction}

The Global Tropospheric Experiment (GTE), undertaken over the past decade by the National 


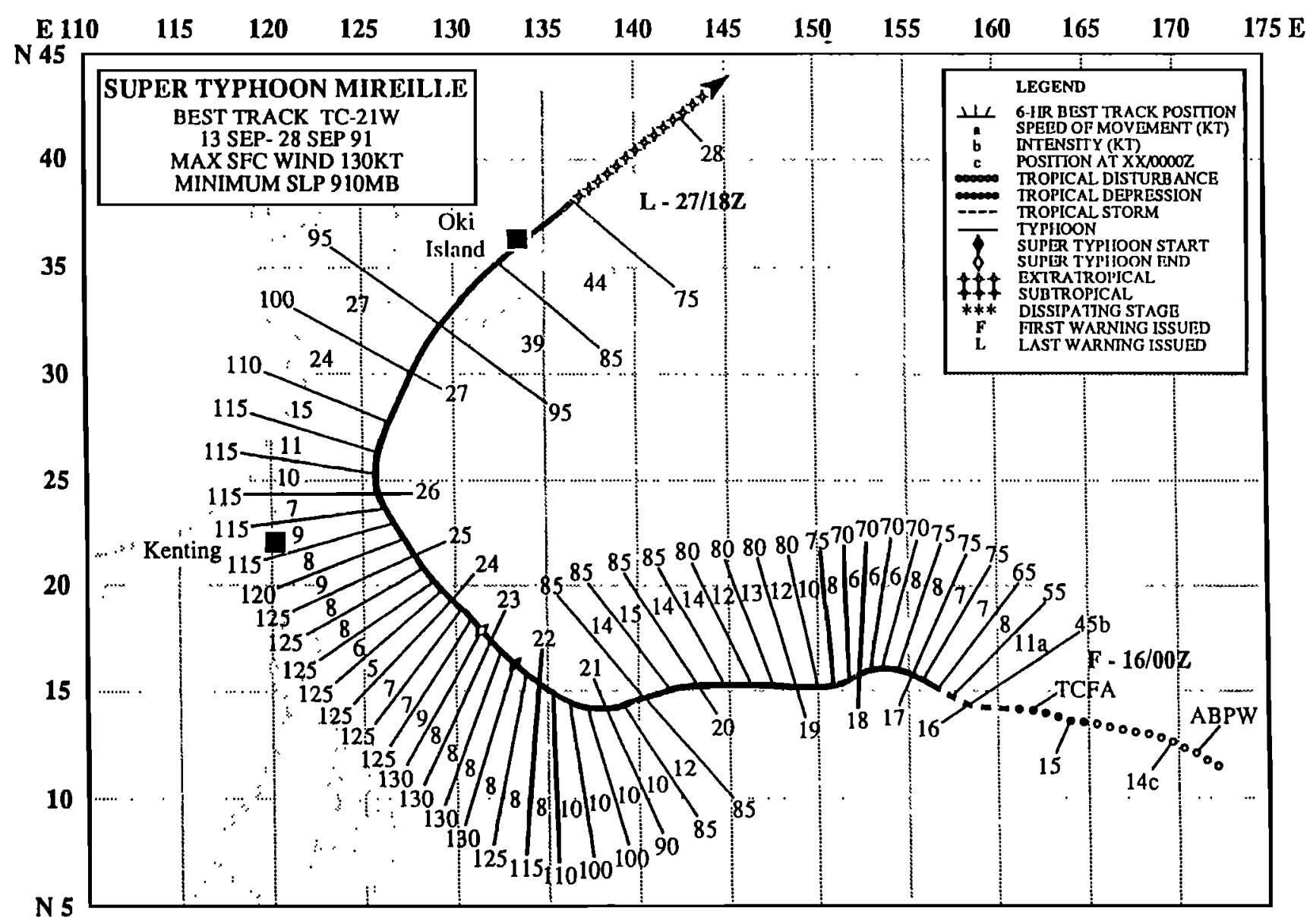

Figure 1. Track of Typhoon Mireille from September 13-28, 1991 [from Rudolph and Guard, 1992]. Positions of ground stations Kenting and Oki Island are noted.

Aeronautics and Space Administration, has carried out atmospheric sampling in various regions of the world. Measurements are used here from flights through a typhoon during the Pacific Exploratory Mission-West A (PEM-West A) NASA DC-8 deployment to the western Pacific in September-October 1991. The instrumentation carried on the DC-8 is described by Hoell et al. [this issue] and the background meteorology by Bachmeier et al. [this issue]. Sampling was planned in two separate seasons: one toward the end of the summer monsoon and the other toward the end of the winter monsoon. The summer monsoon of the tropical western Pacific always includes a number of typhoons; five occurred during the 6 weeks of the first PEM-West deployment. The large-scale manifestation of atmospheric convection that these typhoons represent could be important in the redistribution of atmospheric trace constituents. In some previous discussions of typhoons, there was debate as to why the air mass in the eye was apparently different from the surrounding air mass. Bergeron [1954], referring to the work of others, noted that "The two air masses are separated by a boundary zone which sometimes has been taken for the tropopause itself, sucked down from its normal height... ." In Bergeron's view, "It is more plausible that this boundary zone has been formed by a similar process within the tropospheric air itself." In the present experiment, ozone, a good stratospheric tracer, was measured to test these ideas.
In the typhoon system, there is a substantial lateral inflow of air in the lower troposphere to compensate for the rising convective motions and outflow aloft, and these quasi-horizontal flows are also important in redistributing trace constituents. An opportunity to carry out an experiment to check this redistribution was presented when Typhoon Mireille approached an area to the south of Japan which could be accessed from Tokyo. Air entering the typhoon in the surface boundary layer, in the eye itself, emerging from the eye and surrounding wall cloud region in the upper troposphere, was sampled.

Typhoon Mireille was first noted on the weather maps as a significant system on September 13,1991, when positioned at $12^{\circ} \mathrm{N}, 172^{\circ} \mathrm{E}$ moving westward (see Figure 1) [from Rudolph and Guard, 1992] and qualified as a typhoon, with 1-min sustained winds exceeding $32 \mathrm{~ms}^{-1}$, on September 16 while at $15^{\circ} \mathrm{N}, 157^{\circ} \mathrm{E}$. By September $22^{\prime}$ it had turned toward the northwest and winds had increased to $67 \mathrm{~ms}^{-1}$, qualifying Mireille as a "super typhoon." After September 23, Mireille began to slowly weaken, although its size, as measured by the diameter of its outermost closed isobar, continued to increase. On September 26, Mireille turned northward, then northeastward, and made land in western Kyushu at about 0600 UT on September 27. During the evening of September 27 it passed over the Sea of Japan and gradually lost force, passing over northern Honshu and southern Hokkaido early on September 28. 


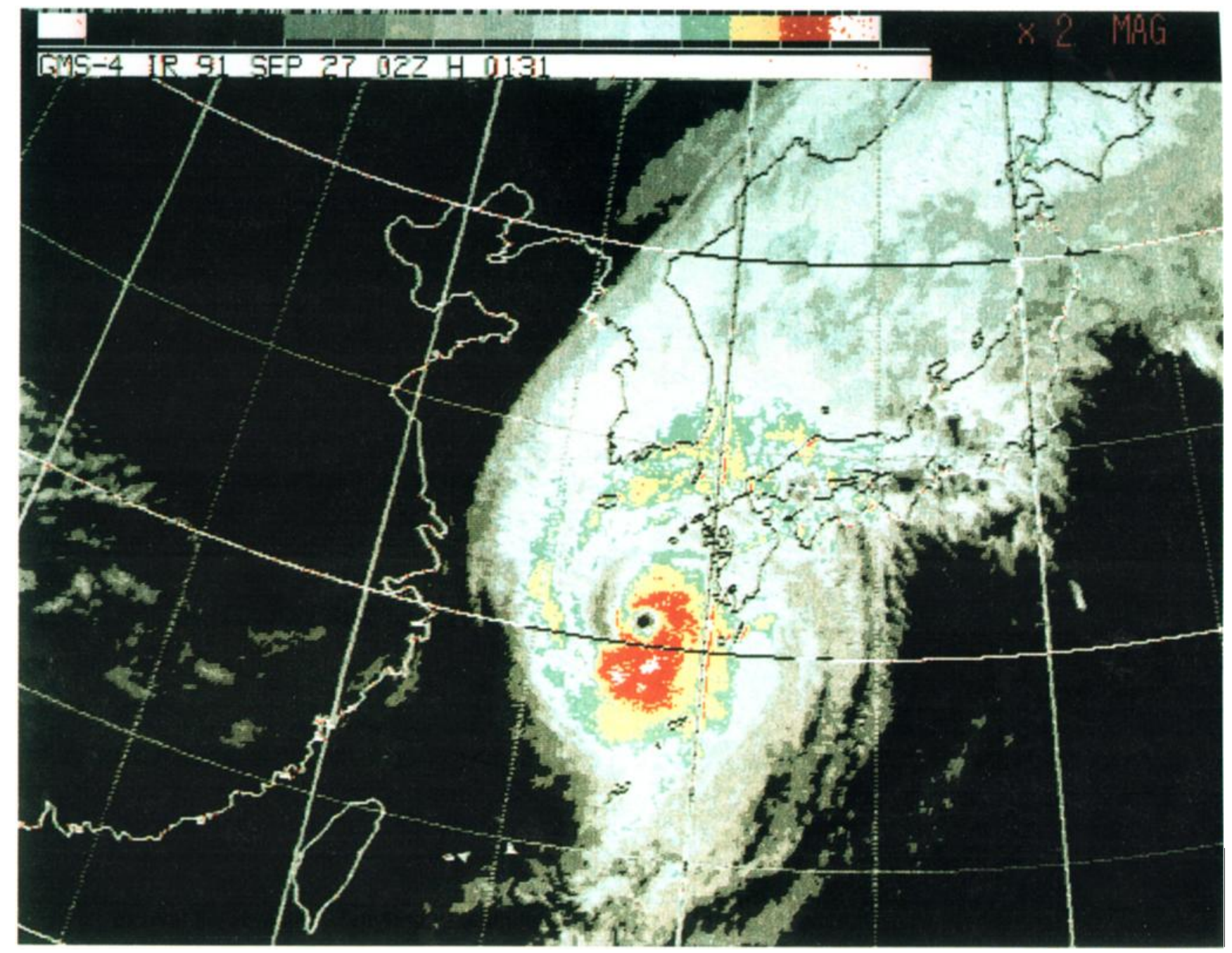

Plate 1. Japanese Geostationary Meteorological satellite image for 0200 UT at time of DC-8 take-off (provided by first Weather Wing at Yokota Air Base).

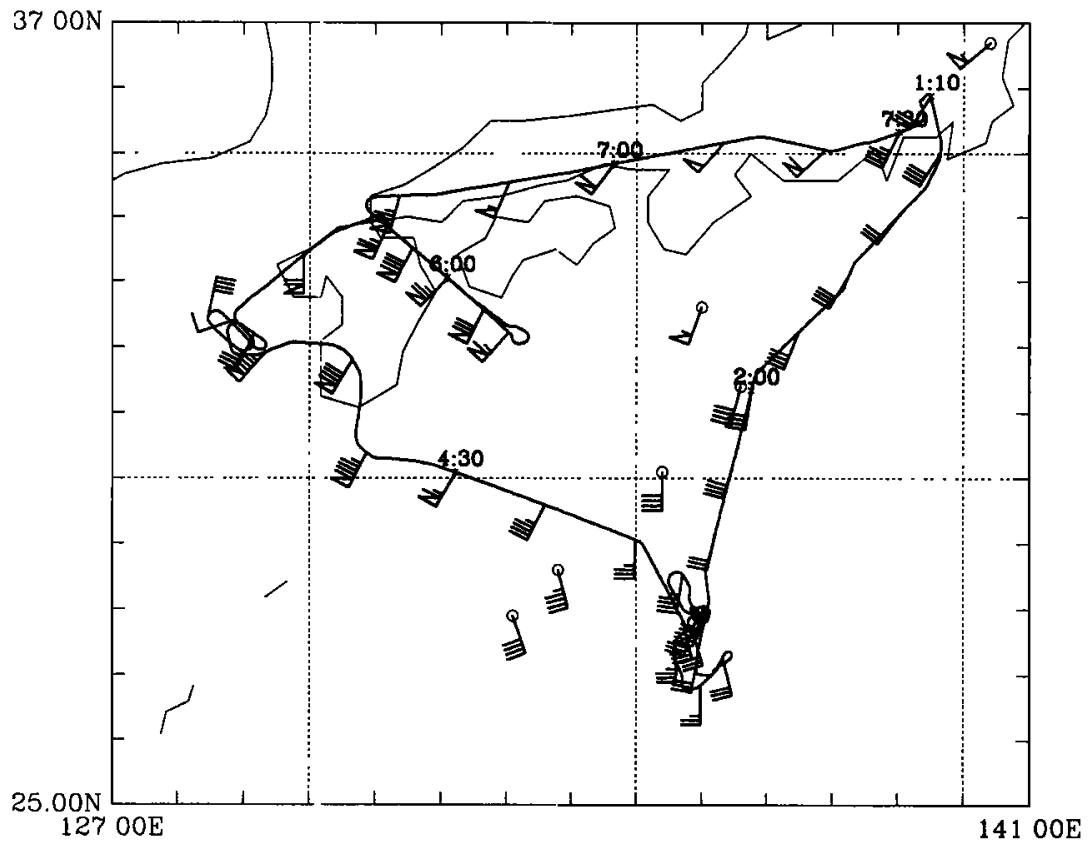

Figure 2. Horizontal projection of flight track, DC-8 measured winds, and additional commercial aircraft flight winds at $288 \mathrm{hPa}$ (data from European Centre for Medium-Range Weather Forecasts (ECMWF) files) for September 27, 1991. Flag, $25 \mathrm{~ms}^{-1}$; a full bar, $5 \mathrm{~ms}^{-1}$; a half bar, $2.5 \mathrm{~ms}^{-1}$. Time interval between $\mathrm{DC}-8$ winds is $10 \mathrm{~min}$. 


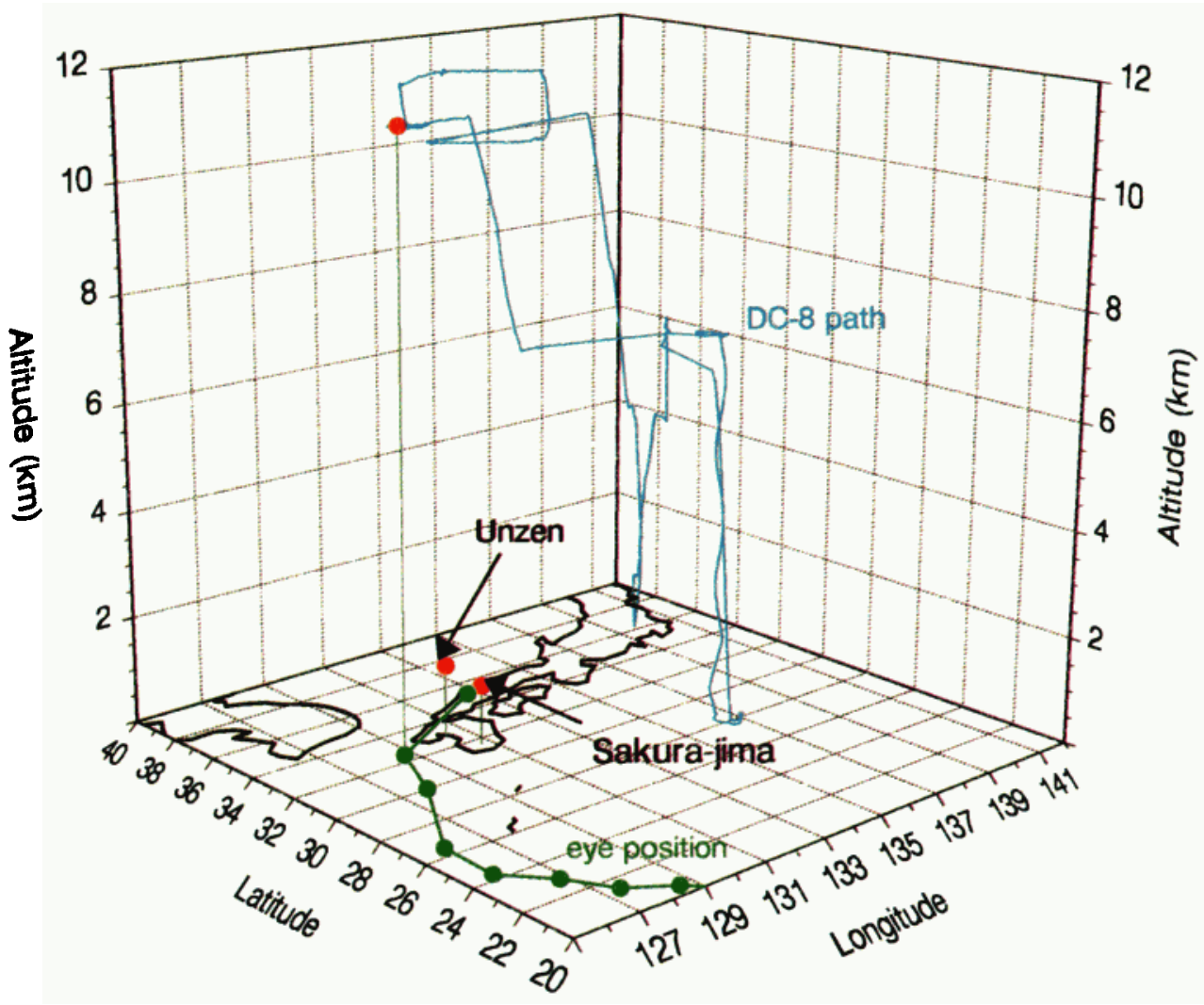

Plate 2. Three-dimensional projection of DC-8 flight.

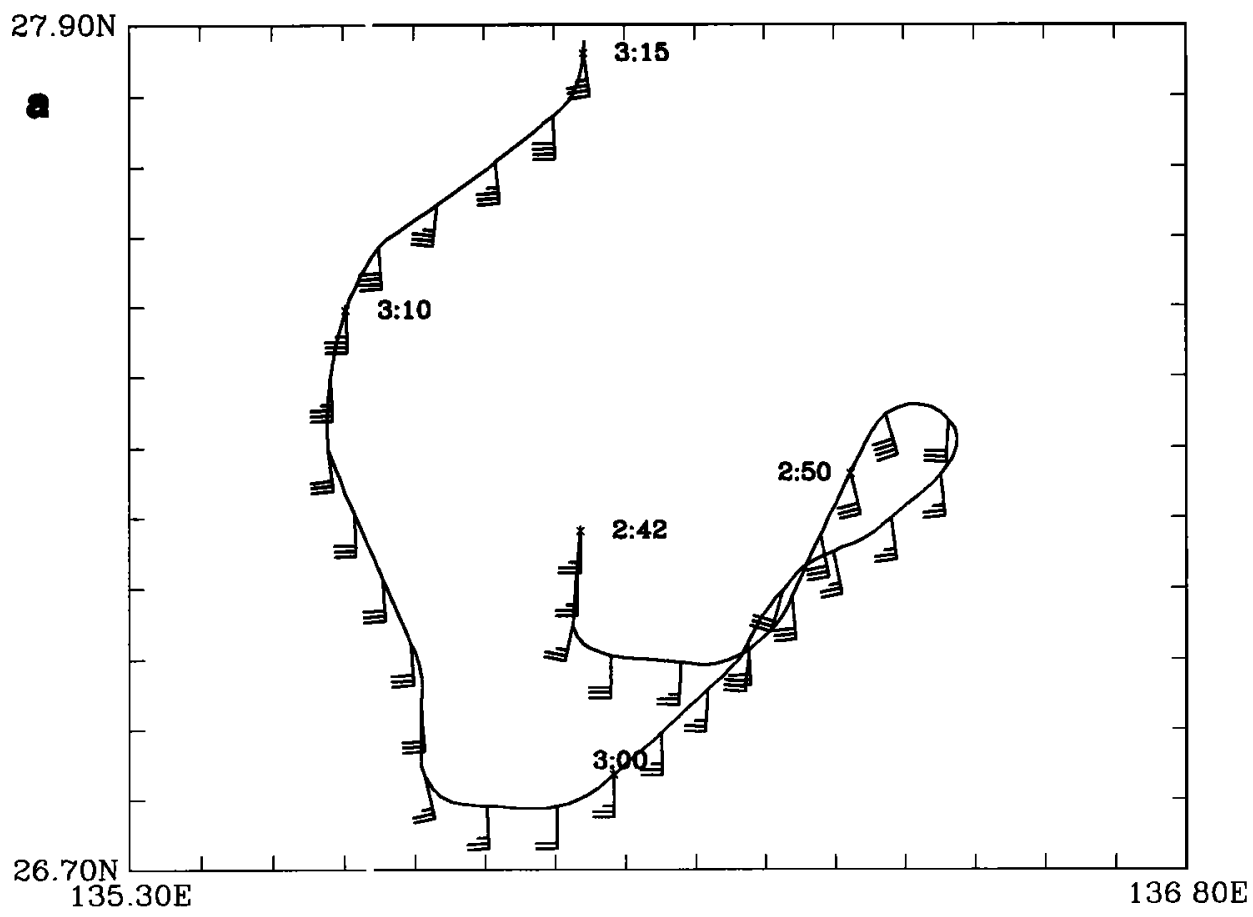

Figure 3. Intensive survey DC-8 flight routes and windis for September 27, 1991. Flag, $25 \mathrm{~ms}^{-1}$; a full bar, $5 \mathrm{~ms}^{-1}$; a half bar, $2.5 \mathrm{~ms}^{-1}$. (a) Boundary layer inflow region, $300 \mathrm{~m}$. Time interval between DC-8 winds is $1 \mathrm{~min}$. (b) Eye region, $11360 \mathrm{~m}$. Time interval between DC-8 winds is $1 \mathrm{~min}$. (c) Outflow region (circles are radiosonde winds at $200 \mathrm{hPa}$ ), $11200 \mathrm{~m}$. Time interval between DC-8 winds is 2 $\min$. 

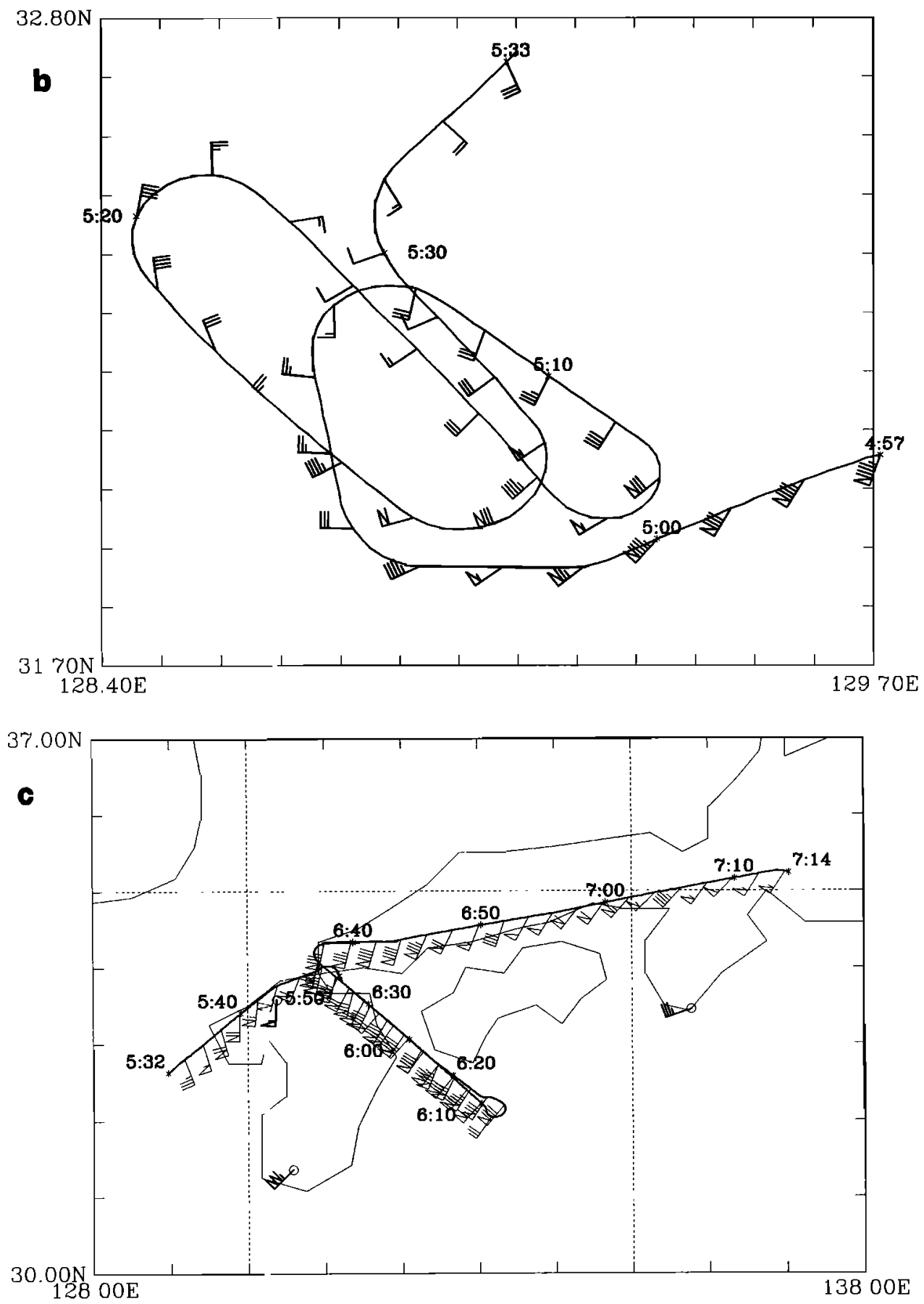

Figure 3. (continued)

The NASA DC-8 left Yokota Air Base, Tokyo, at 0105 UT on September 27, 1991, as Mireille approached Kyushu from the southwest with a central pressure of 935 hPa. A boundary layer run at $300 \mathrm{~m}$ was made at about $28^{\circ} \mathrm{N}, 136^{\circ} \mathrm{E}$, and the aircraft then climbed to $11.3 \mathrm{~km}$ and penetrated the cloud region surrounding the eye (see Plate 1 satellite image) which, according to cloud top temperatures and vertical temperature profiles, exceeded $15.5 \mathrm{~km}$ in height. The overall aircraft track is summarized in the horizontal projection of Figure 2, which includes the aircraft-measured wind velocities, and in the vertical cross section of Plate 2. The DC-8 entered the eye at about 0457 UT through a gap in the highest clouds and remained in the eye, which by then was beginning to fill in with clouds, until about 0535 UT, then exited to the northeast. At 0550 UT the aircraft headed toward the southeast at 12 km and returned along the same path, heading northwest, at $11 \mathrm{~km}$. The purpose was to sample the atmosphere more or less perpendicular to the outflow from Mireille. At 0638 UT, the end of this maneuver, the DC-8 turned toward the east-northeast and returned toward Tokyo, where it landed at $0739 \mathrm{UT}$. 

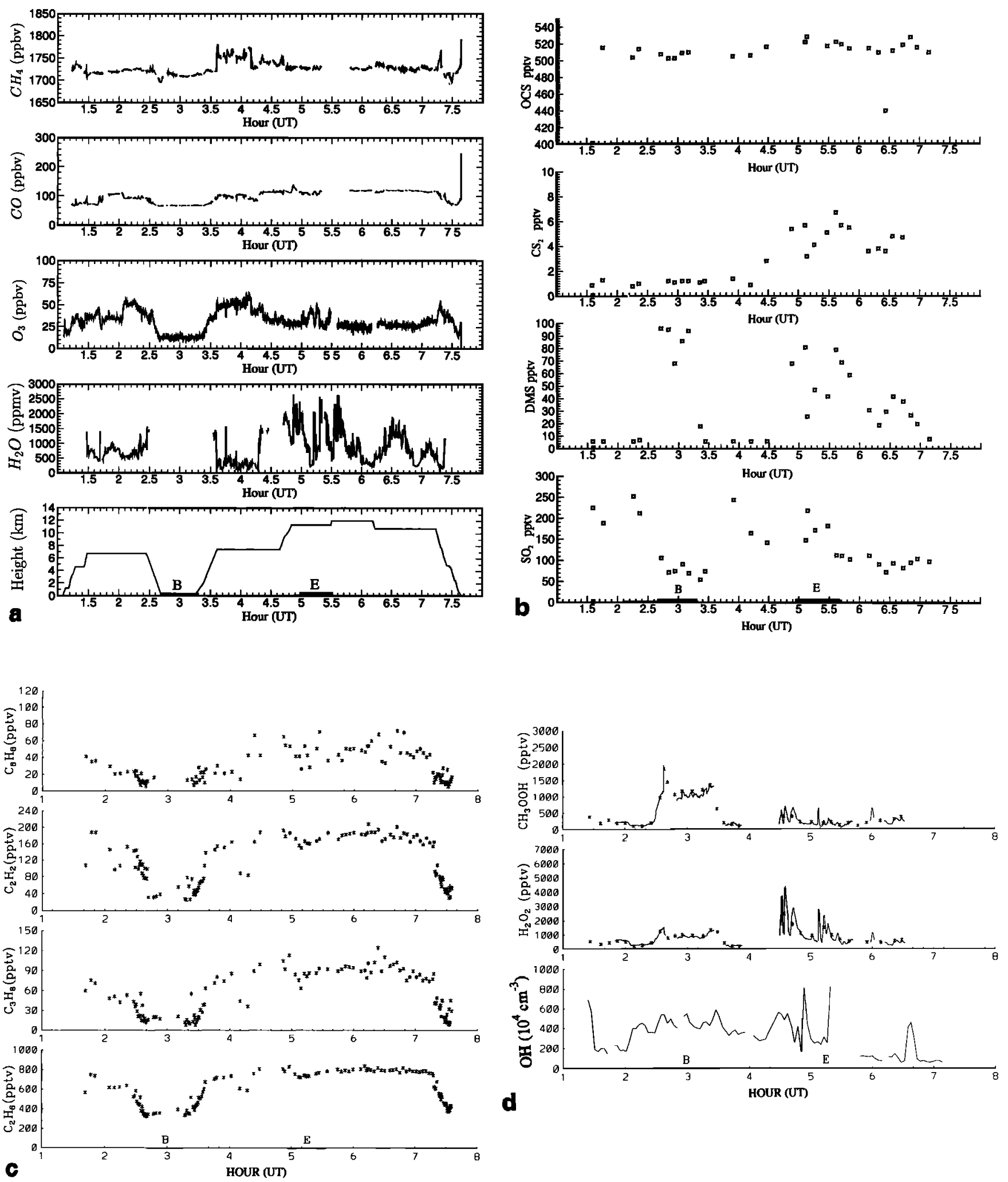

Figure 4. Time series of selected constituents for the entire flight for September 27, 1991. B represents boundary layer run ( $0242 \mathrm{UT}-0315 \mathrm{UT})$ and $\mathrm{E}$ represents time spent in typhoon eye region ( $\sim 0457 \mathrm{UT}-0533 \mathrm{UT})$. (a) $\mathrm{CH}_{4}, \mathrm{CO}_{3} \mathrm{O}_{3}$, and $\mathrm{H}_{2} \mathrm{O}$ mixing ratio from Lyman- $\alpha$ instrument (plus flight altitude). Resolution of data used: $\mathrm{CO}$ and $\mathrm{CH}_{4}, 5 \mathrm{~s} ; \mathrm{O}_{3}, 10 \mathrm{~s}$; $\mathrm{H}_{2} \mathrm{O}, 10$ s. (b) $\mathrm{OCS}, \mathrm{CS}_{2}, \mathrm{DMS}$, and $\mathrm{SO}_{2}$. (c) $\mathrm{C}_{6} \mathrm{H}_{6}$ (benzene), $\mathrm{C}_{2} \mathrm{H}_{2}$ (ethyne [acetylene]), $\mathrm{C}_{3} \mathrm{H}_{8}$ (propane), and $\mathrm{C}_{2} \mathrm{H}_{6}$ (ethane). (d) $\mathrm{CH}_{3} \mathrm{OOH}$ (methyl-hydroperoxide), $\mathrm{H}_{2} \mathrm{O}_{2}$ (hydrogen peroxide), and $\mathrm{OH}$ from model by Davis et al. [this issue]. (e) NO, NO $\mathrm{y}_{\mathrm{y}}$, peroxyacetyl nitrate (PAN), and ambient temperature (difference between GIT and Kondo discussed by Crosley [this issue]). (f) Aerosol concentrations. (g) Ratios of acetylene/CO and propane/ethane. (h) Detailed (10 s) temperature, water vapor, aircraft wind speed, and aircraft altitude from 0500 to 0700 UT. 

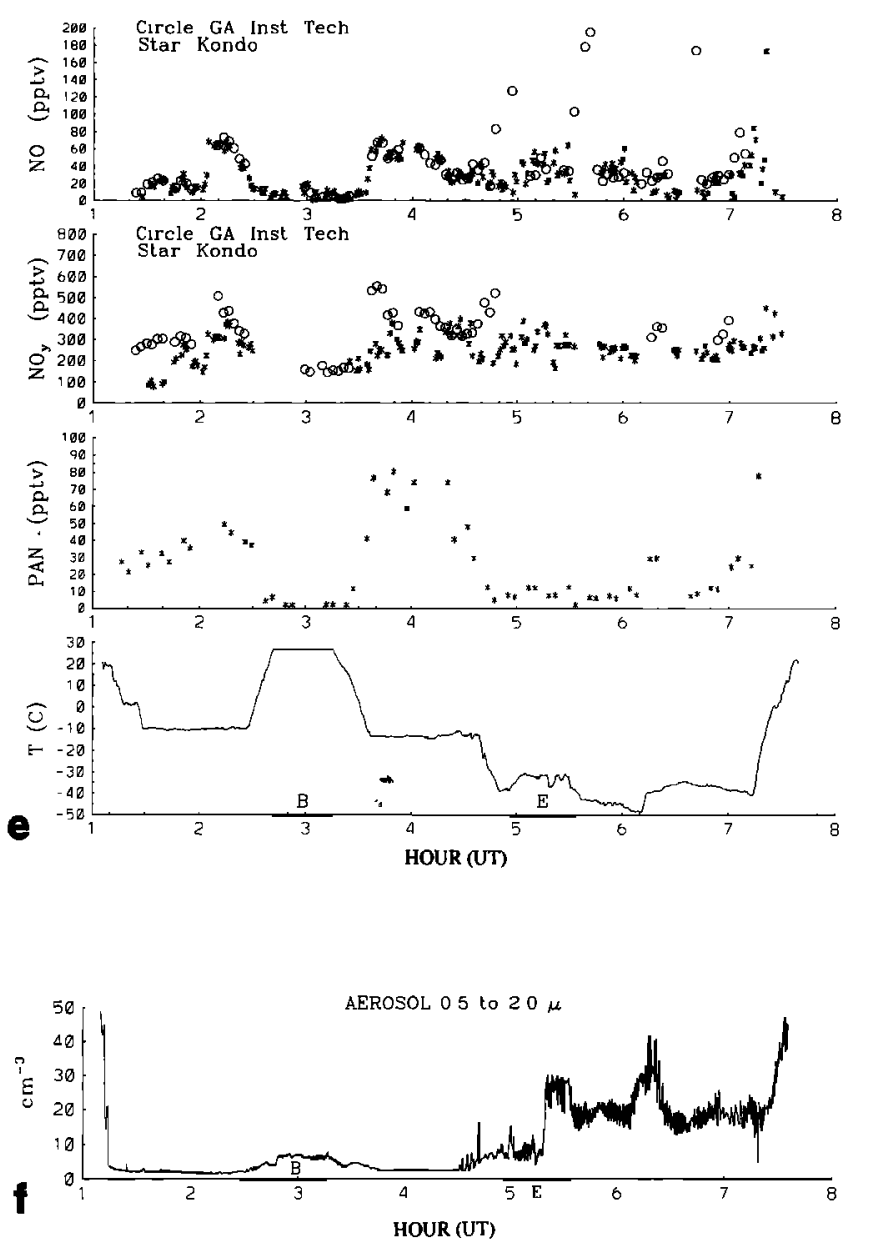
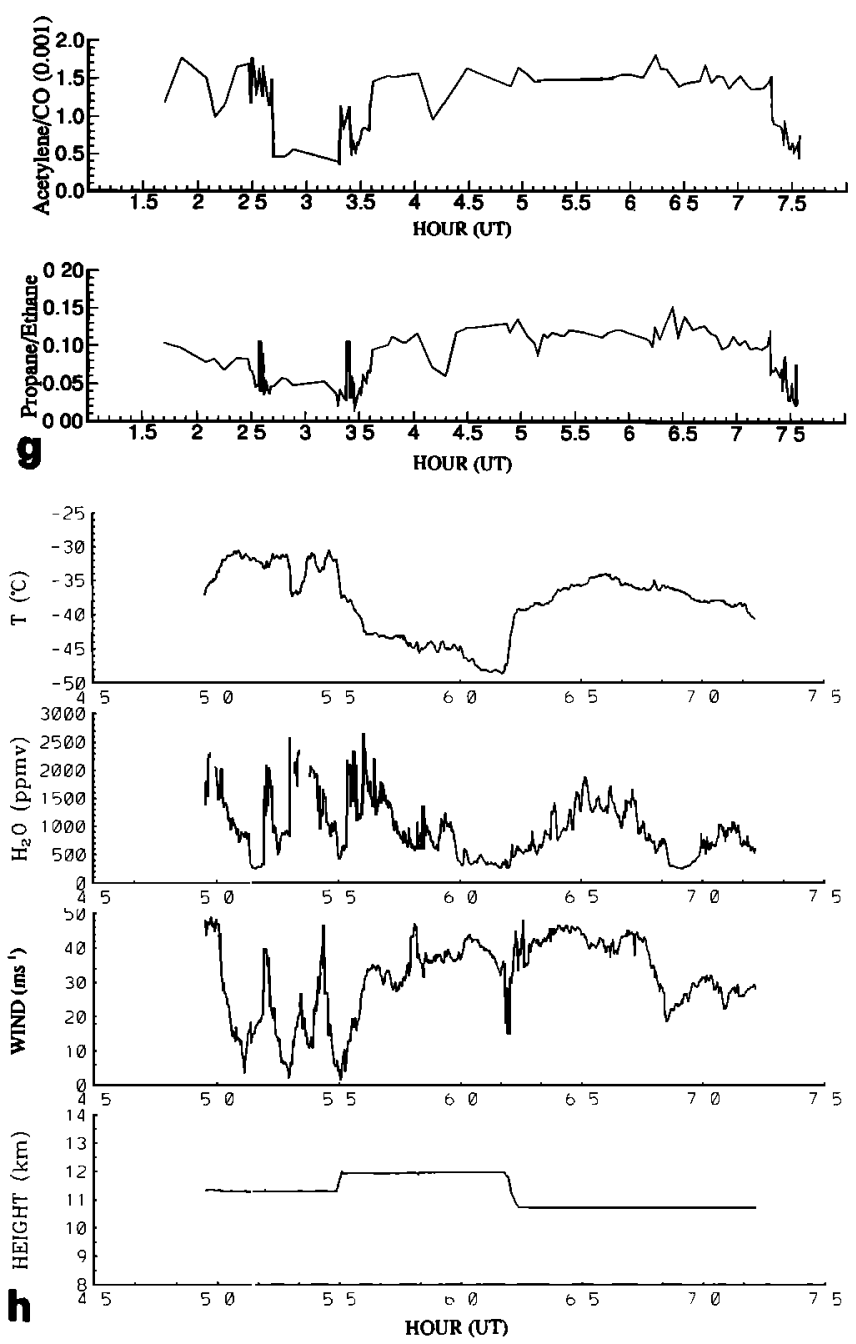

Figure 4. (continued)

Intensive sampling was carried out in three regions: the boundary layer inflow region at about $300 \mathrm{~m}$ between $0241 \mathrm{UT}$ and $0315 \mathrm{UT}$; the eye and surrounding wall cloud region, sampling at about 11.3 and $12 \mathrm{~km}$ between 0457 and $0535 \mathrm{UT}$; and the outflow region (a term used here to denote the northeast quadrant) between 0550 and 0714 UT. The aircraft-reported winds are plotted in Figure 3a-3c for these three regions. Where available, radiosonde winds (see, for example, Figure 3c) and winds from commercial aircraft flights (AIREPs) are also included (see, for example, Figure 2). Most of the body of this paper deals with the atmospheric chemistry findings in these three regions and their possible interpretation in terms of atmospheric motions.

\section{Results of Boundary Layer Sampling}

Time series of selected constituents are examined first to place the boundary layer inflow region in proper perspective. Figure 4 includes time series for the entire mission of $\mathrm{CH}_{4}, \mathrm{CO}, \mathrm{O}_{3}, \mathrm{H}_{2} \mathrm{O}, \mathrm{OCS}, \mathrm{CS}_{2}, \mathrm{CH}_{3} \mathrm{SCH}_{3}$ (DMS), $\mathrm{SO}_{2}, \mathrm{C}_{2} \mathrm{H}_{2}, \mathrm{C}_{2} \mathrm{H}_{6}, \mathrm{C}_{3} \mathrm{H}_{8}, \mathrm{C}_{6} \mathrm{H}_{6}, \mathrm{NO}, \mathrm{NO}_{\mathrm{y}}$, $\mathrm{CH}_{3} \mathrm{C}(\mathrm{O}) \mathrm{OONO}_{2}$ (peroxyacetyl nitrate (PAN)), $\mathrm{H}_{2} \mathrm{O}_{2}$, $\mathrm{CH}_{3} \mathrm{OOH}, \mathrm{OH}$ (model calculated), and aerosol. Figure 4a also contains the flight altitude, and Figure $4 \mathrm{e}$ includes ambient air temperature. Time resolution of the data used in Figure $4 \mathrm{a}$ is given with the Figure $4 \mathrm{a}$ caption. For other constituents the data are collected at variable intervals and are plotted at the midpoint of the collection interval. Each time series set has the boundary layer and eye regions marked on the time axis. Constituents having their lowest $\mathrm{C}_{2} \mathrm{H}_{6}, \mathrm{C}_{3} \mathrm{H}_{8}, \mathrm{C}_{6} \mathrm{H}_{6}, \mathrm{NO}, \mathrm{NO}_{\mathrm{y}}$, and PAN. PAN is actually below the detection limit; its concentration is very sensitive to temperature, decreasing at higher temperatures [Singh, 1987]. Thus indications are that the air entering the typhoon from the south in the southeastern sector is clean marine air. The marine origin of the inflow was also indicated by the fact that the highest DMS values of the mission occurred in the boundary layer. The higher aerosol concentrations in the boundary layer (Figure 4f) are thought to be associated with sea salt.

In addition to the time series of constituents themselves, time series of ratios of two pairs of constituents which can be interpreted in terms of air mass age are presented in Figure 4g. As discussed elsewhere [Gregory et al., this issue], an acetylene/CO ratio of $<0.5$ corresponds to wellaged air, while a ratio $>1$ suggests emissions only a few days old. These values apply when acetylene is expressed in pptv and $\mathrm{CO}$ is in ppbv. The lifetime of acetylene $\left(\mathrm{C}_{2} \mathrm{H}_{2}\right)$ is about 11 days, while that of carbon monoxide is values in the boundary layer included $\mathrm{CO}, \mathrm{O}_{3}, \mathrm{SO}_{2}, \mathrm{C}_{2} \mathrm{H}_{2}$, 


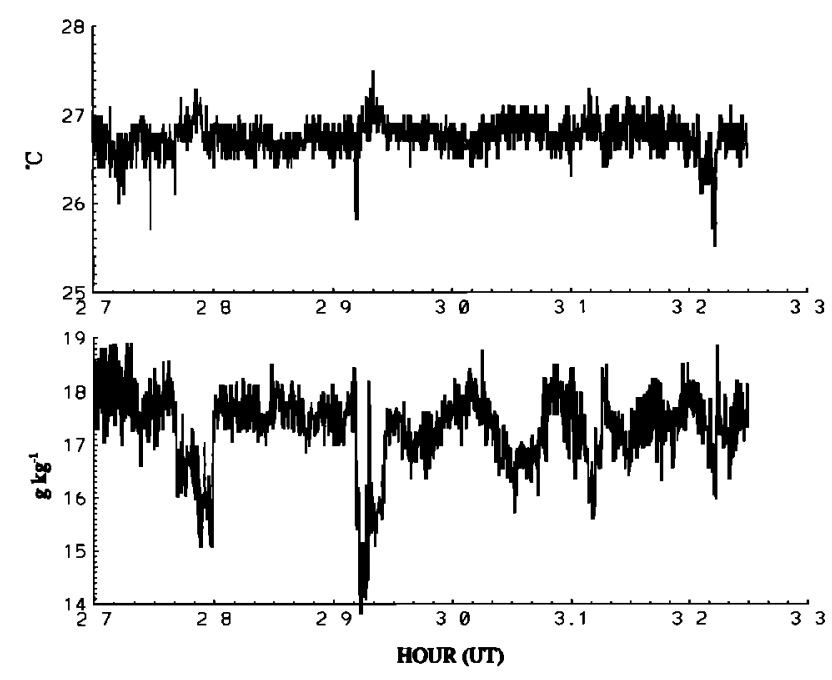

Figure 5. Time series of DC-8 1-s sampling of temperature and specific humidity during boundary layer run at about $300 \mathrm{~m}$. Units, degrees Celsius and grams per kilogram.

about 34 days; by contrast, under the same conditions, DMS would have a lifetime of approximately 2 days. (These lifetime estimates use a diurnally averaged $\mathrm{OH}$ level of $1.4 \times 10^{6} \mathrm{~cm}^{-3}$ which was based on averaged atmospheric conditions during PEM-West A centered around a latitude of $30^{\circ} \mathrm{N}$ [see Davis et al., this issue;

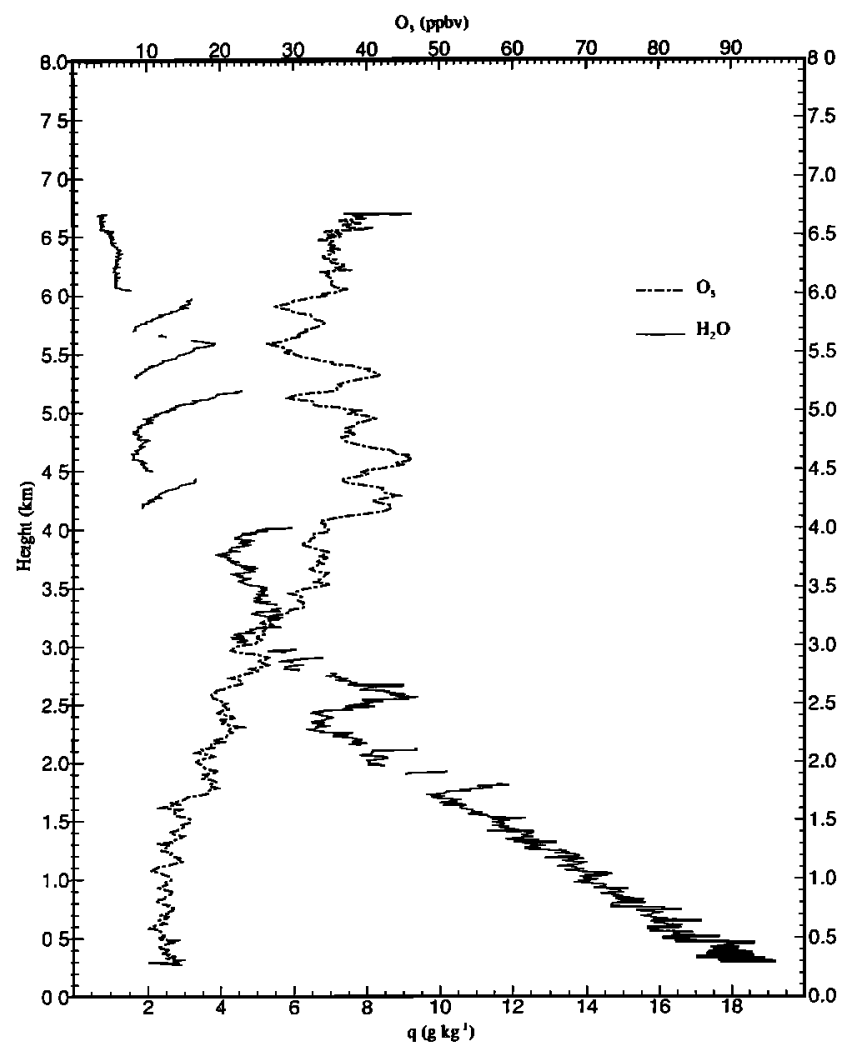

Figure 6. Vertical profiles of specific humidity and ozone from DC-8 measurements. This profile was made during the descent to the boundary layer between 0223 UT and 0242 UT on September 27, 1991.
Rodriguez et al., unpublished material, 1995].) The same general view is given by the propane/ethane ratio; these two gases have lifetimes of 8 and 34 days (see above comment on $\mathrm{OH}$ levels). Using all of the above criteria, the boundary layer air entering from the south can be considered well aged. Further comments about the hydrocarbon data are given below.

The water vapor mixing ratios and aircraft temperatures for the tropical boundary layer are shown together in Figure 5, from which it can be seen that higher temperatures are associated with drier air; correlation coefficients between these two variables are about -0.5 . The spatial separation of the descending dry plumes is tens of kilometers, as may be seen from a map of specific humidity during the boundary layer sampling (not shown). The higher temperatures at $300 \mathrm{~m}$ are produced by subsidence, implying a downward heat transport by these motions. Because sinking motions are relatively dry and, as will be seen later, there is overall convergence into the typhoon region in the lower levels, rising motions in the same area will be relatively moist, and the net effect is an upward transport of moisture. There is a large vertical gradient of $\mathrm{H}_{2} \mathrm{O}$ mixing ratio in the lowest $2 \mathrm{~km}$, as seen from vertical profiles made on descent to and ascent from the boundary layer (an example is shown in Figure 6, to be discussed below). This is maintained by the strong winds $\left(>15 \mathrm{~ms}^{-1}\right)$ and consequent high evaporation from the surface. The temperature gradient between $850 \mathrm{hPa}(1.5$ $\mathrm{km})$ and $300 \mathrm{~m}$ is about $6.5^{\circ} \mathrm{C} \mathrm{km}^{-1}$, close to moist adiabatic. The subsiding plumes are an important factor in ventilating the boundary layer with air from the free troposphere.

Other species measured in the boundary layer, but not illustrated here, include ${ }^{7} \mathrm{Be}$, which has a concentration of $46 \mathrm{fCi} \mathrm{m}^{-3}$ relatively low compared with values of over $200 \mathrm{fCi} \mathrm{m}^{-3}$ in the upper troposphere, and ${ }^{210} \mathrm{~Pb}$, which has a value of $3.6 \mathrm{fCi} \mathrm{m}^{-3}$, quite similar to two other measurements in the upper troposphere made before penetration of the eye and not far from the value measured in the eye. Well ahead of the eye, a final fifth measurement yielded $\sim 0.5 \mathrm{fCi} \mathrm{m}^{-3}$. These data are obtained from aerosol collection and typically involve sampling times of 30-40 min.

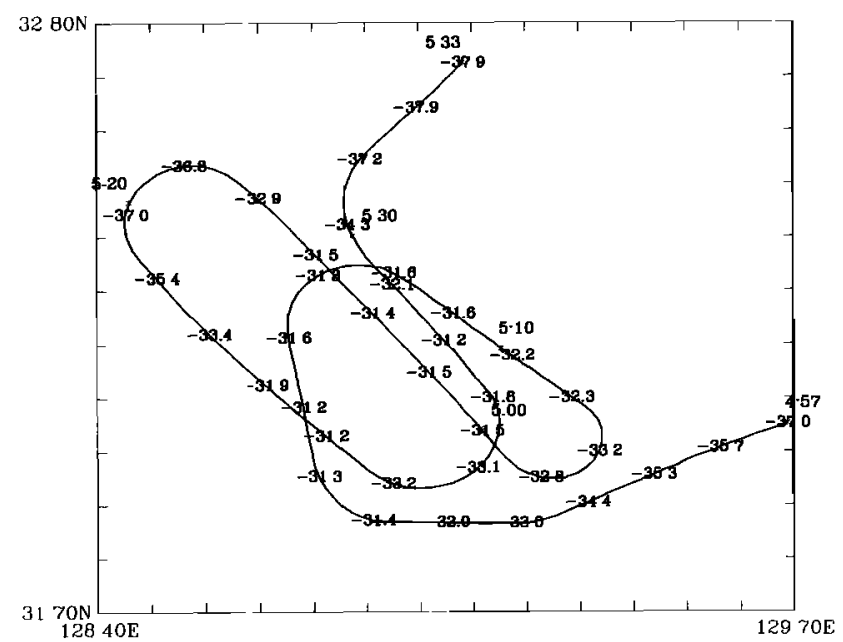

Figure 7. Map of DC-8 air temperature in vicinity of eye at about $11.3 \mathrm{~km}$ on September 27, 1991. Points are $60 \mathrm{~s}$ apart. Units, degrees Celsius. 


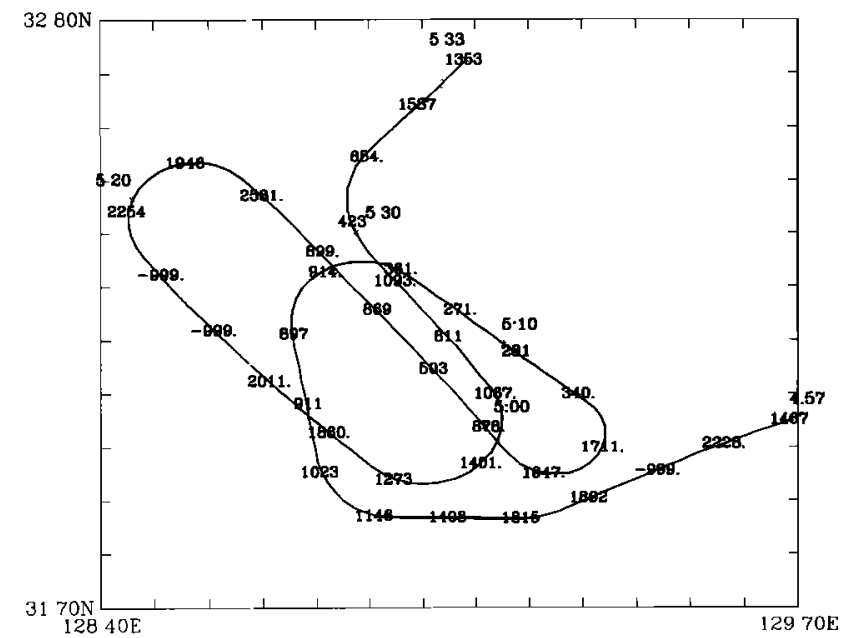

Figure 8. Map of DC-8 water vapor mixing ratio in vicinity of eye at about $11.3 \mathrm{~km}$ on September 27, 1991. Points are $60 \mathrm{~s}$ apart. Units, parts per million by volume.

\section{Results of Sampling in Eye and Wall Cloud Region}

The aircraft reached the eye at about 0500 UT at 11.3 $\mathrm{km}$ and ascended to about $11.9 \mathrm{~km}$ between 0528 and $0530 \mathrm{UT}$, just before leaving the eye. The DC-8 1-min air temperatures are mapped in Figure 7; the eye center is about $6^{\circ} \mathrm{C}$ higher than its surroundings (compare 0457 , 0517 , and 0520 UT values). Temperature values every $10 \mathrm{~s}$ are in Figure $4 \mathrm{~h}$ and show variation of up to $6^{\circ} \mathrm{C}$ in the eye. Sinking motion in the eye with concomitant compression and adiabatic warming is suggested and would account for the lack of cloud there in the GMS images at and before $0000 \mathrm{UT}$. A relevant schematic of this type of circulation has been given by Willoughby [1988]. The water vapor mixing ratio measured by the Lyman- $\alpha$ instrument showed quite dry patches, 270-500 parts per million by volume (ppmv), in some regions of the eye, again suggesting subsidence, mixed with values up to $2580 \mathrm{ppmv}$, and it appears that cloud particles could also be involved in the latter (Figure 8). Patchy clouds were quite abundant within the eye region, and these may be responsible for the high aerosol concentration after 0518 UT. The ozone concentrations in the eye region (Figures 9 and $4 a)$ are relatively low ( $25-30$ parts per billion by volume (ppbv)), although there are a few spikes up to $40-50 \mathrm{ppbv}$ in the central drier region, but there are no high values (>100 ppbv) as might be expected if stratospheric air was present. Suggestions have been made that stratospheric air could be entrained into the eye, but these ozone measurements suggest that Bergeron [1954] provided a more attractive explanation of the higher temperatures in the eye by arguing, as noted earlier, that the subsidence responsible occurred within the troposphere. Nevertheless, there may be small-scale intrusions of stratospheric air into the upper troposphere well above the aircraft, and one possible example is included in the ozone lidar cross section of Plate 3a. The concomitant aerosol lidar cross section shows cirrus cloud almost completely covering the eye at about $16 \mathrm{~km}$, thus indicating no large-scale sinking motion at that level. It is also worth noting that the highest ${ }^{7} \mathrm{Be}$ concentration is 200 $\mathrm{fCi} \mathrm{m}^{-3}$ in the upper troposphere and about $80 \mathrm{fCi} \mathrm{m}^{-3}$ in

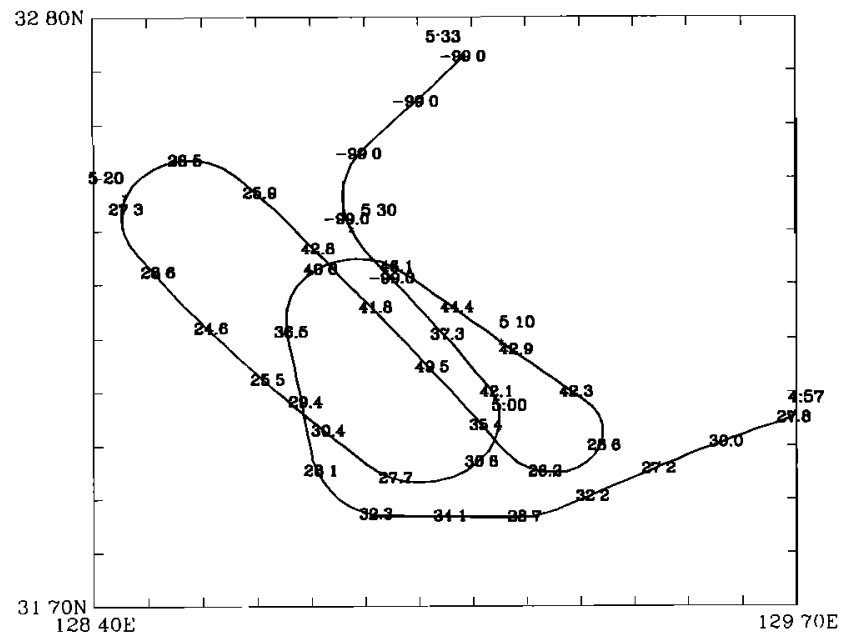

Figure 9. Map of ozone in vicinity of the eye at about $11.3 \mathrm{~km}$ September 27, 1991. Points are $60 \mathrm{~s}$ apart. Units, parts per billion by volume.

the eye, compared with typical values of about 2000 $\mathrm{fCi} \mathrm{m}^{-3}$ in the stratosphere. Again the implication is that stratospheric air is not being drawn down into the eye region. The lidar cross sections (Plates $3 a$ and $3 b$ ) show very low ozone inside the eye, generally characteristic of equatorial boundary layer air, from $5 \mathrm{~km}$ to a height of about $16 \mathrm{~km}$. The gap in coverage in the 0511-0513 UT period in these images occurs when the aircraft was turning into the wall cloud from the north (see Figure 8 water vapor values). It is also worth noting that there is a negative correlation between $\mathrm{H}_{2} \mathrm{O}$ and $\mathrm{O}_{3}$ in the time series and generally a positive correlation between $\mathrm{H}_{2} \mathrm{O}$ and wind speed (cf. Figure 4h). This indicates that moist, highvelocity air has less ozone than dry slower-moving air, it can be inferred from the limited radiosonde data available that wind speeds are decreasing above $\sim 12 \mathrm{~km}$, so the latter air is subsiding. Carbon monoxide is characteristically low in the stratosphere $(\sim 50 \mathrm{ppbv})$ and can also be used as a tracer of stratospheric air; but in this case (Figure 4a), the boundary layer air gave the lowest value $(\sim 70 \mathrm{ppbv})$, and the air ahead of the typhoon showed $115-120 \mathrm{ppbv}$ (Figure 4a), so the fact that the eye contained a few values in the 103-110 ppbv (Figure 10) range could not be interpreted as indicating stratospheric air; in fact, it could be claimed that some of the air originated from the boundary layer. It was noted earlier that DMS had its highest values in the boundary layer ( $\sim 90$ parts per trillion by volume (pptv); see Figure 4b). After the DC-8 left the boundary layer, DMS values returned to their limit of detection until 0454 UT, just before entering the wall cloud convection region; at that point they increased to $80 \mathrm{pptv}$. In the eye, there were three observations: 25,42 , and 48 pptv (see Figure $4 \mathrm{~b}$ ). On leaving the eye at $0537 \mathrm{UT}$, high values $(78 \mathrm{pptv})$ were again associated with the wall cloud region; values are considerably lower in the outflow region, as may be seen from Figure $4 \mathrm{~b}$, adding weight to the interpretation that the highest values are transported from the boundary layer into the upper troposphere in the wall cloud region. Some of this wall-cloud air sinks into the eye, while the remainder moves away from the typhoon in the upper troposphere.

In general, tracer species showed a range of mixing ratio patterns when viewed in the boundary layer, the free troposphere ahead of the eye, and the eye itself. For example, the mixing ratios of ${ }^{7} \mathrm{Be}, \mathrm{O}_{3}, \mathrm{C}_{2} \mathrm{H}_{2}, \mathrm{C}_{2} \mathrm{H}_{8}, \mathrm{C}_{3} \mathrm{H}_{8}$, $\mathrm{C}_{6} \mathrm{H}_{6}, \mathrm{CS}_{2}$, and $\mathrm{CO}$ were lowest in the boundary layer, 


\section{TYPHOON}

PEM WEST-A FLIGHT 9
27 SEP 91

RELATIVE AEROSOL SCATTERING (IR)
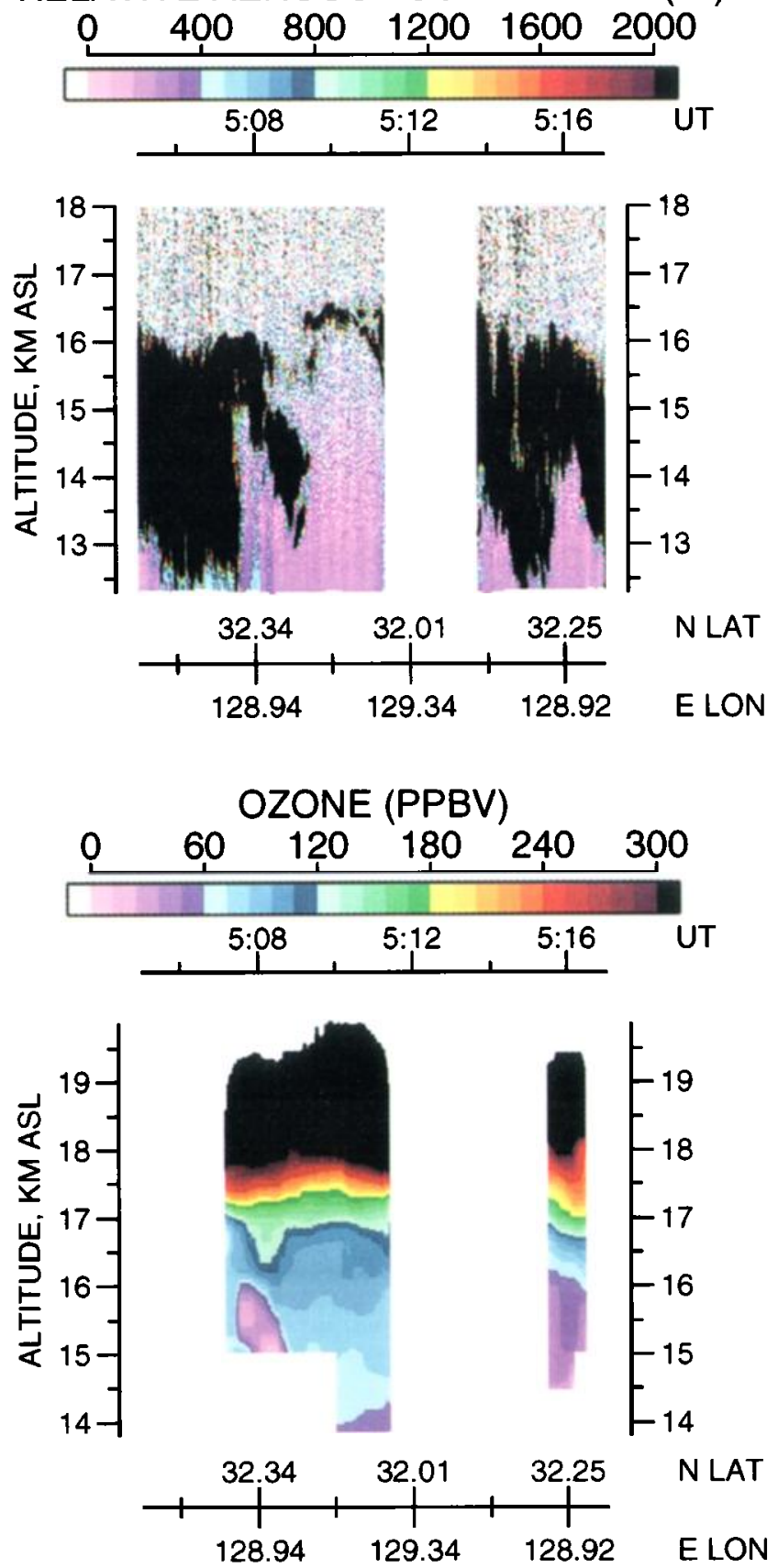

Plate 3. Airborne lidar aerosol and ozone cross sections of the eye region. (a) Looking up. (b) Looking down. 
TYPHOON

\section{$\begin{array}{lll}\text { PEM WEST-A } & \text { FLIGHT } 9 & 27 \text { SEP } 91\end{array}$}
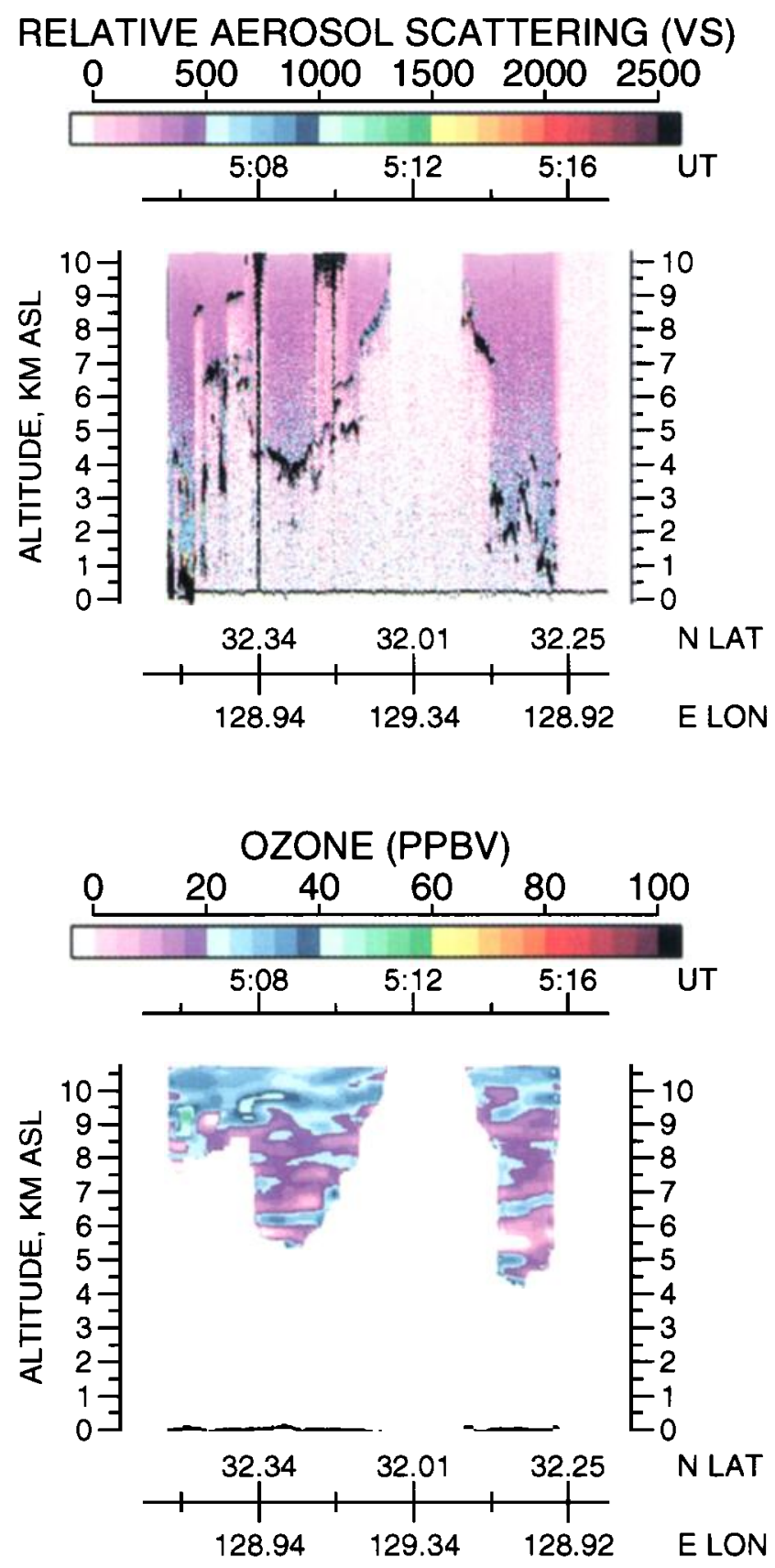

Plate 3. (continued) 


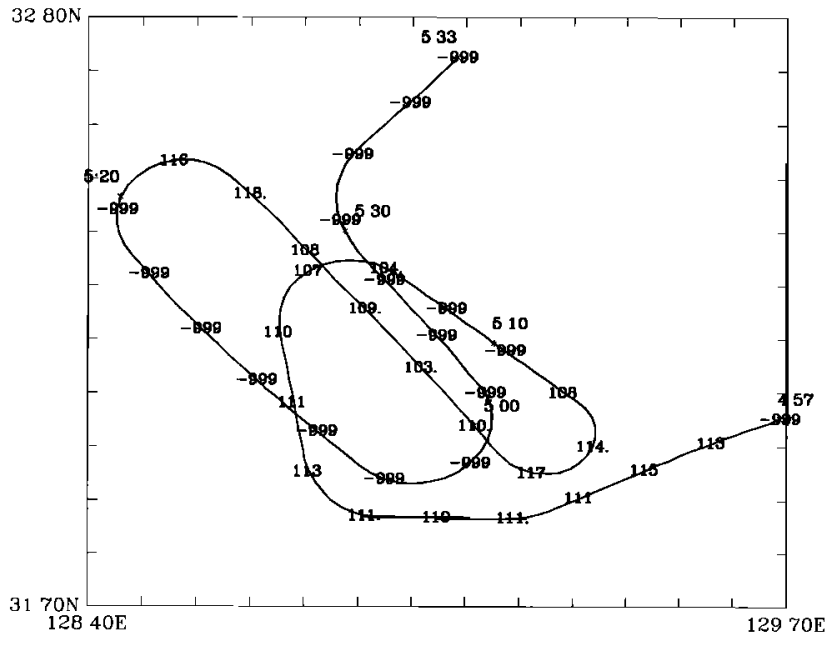

Figure 10. Map of carbon monoxide in eye region at about $11.3 \mathrm{~km}$ on September 27, 1991. The time interval between closely spaced points is about $60 \mathrm{~s}$. There are a number of missing data points. Units, parts per billion by volume.

while DMS was highest. Approximate mixing ratio values for several of these species (e.g., ${ }^{7} \mathrm{Be}, \mathrm{O}_{3}, \mathrm{CS}_{2}$, and $\mathrm{CO}$ ) for all three regions are shown in Table 1 , together with the deduced fraction of boundary layer air that, when mixed with air from the free troposphere, accounts for the observed mixing ratios in the eye. Problems arise from the assumption that the eye air is drawn only from two sources, from the fact that the boundary layer air sampled was far removed from the boundary layer contributing most directly to the wall cloud region and from the fact that the free troposphere contribution came from a varicty of air masses that were entrained horizontally by the typhoon system. Nevertheless, these results suggest that a significant fraction of the air in the eye wall region could have originated from the boundary layer.

The four hydrocarbons shown in Figure $4 \mathrm{c}$ all increased with altitude and were found to be higher in and ahead of the eye than in the boundary layer. The hydrocarbons are only slightly diluted, if at all, in the eye wall region, suggesting they may have originated (see comments below) from the continent. Carbon disulfide $\left(\mathrm{CS}_{2}\right)$ may have had a similar path as the NMHCs. Still another possibility is that the boundary layer which is in direct

Table 1. Mixing Ratios in Boundary Layer, Free

Troposphere, and Eye Region at 11-12 km

Together With Resulting Fraction of Air in the Eye Derived From the Boundary Layer

Boundary Free \% of Eye

Layer(BL) Troposphere Eye From BL

\begin{tabular}{lrrrr}
$\mathrm{CO}, \mathrm{ppbv}$ & 70.0 & 116.0 & 105.0 & 24.0 \\
${ }^{7} \mathrm{Be}, \mathrm{fCi} \mathrm{m}^{-3}$ & 46.0 & 205.0 & 81.0 & 78.0 \\
$\mathrm{DMS}, \mathrm{pptv}$ & 94.0 & 6.0 & 38.0 & 36.0 \\
$\mathrm{O}_{3}, \mathrm{ppbv}$ & 15.0 & 55.0 & 30.0 & 62.0 \\
$\mathrm{C}_{2} \mathrm{H}_{2}, \mathrm{pptv}$ & 30.0 & 185.0 & 160.0 & 16.0 \\
$\mathrm{CS}_{2}, \mathrm{pptv}$ & 1.0 & 5.8 & 4.5 & 27.0 \\
\hline
\end{tabular}

contact with the wall cloud region, may have had higher concentrations of some of these constituents than were measured in the boundary layer to the southeast of the storm. In considering the latter hypothesis, it is important to keep in mind that while the sampled boundary layer was over the open ocean, the air which fed directly into the wall cloud was over the southern portion of Kyushu at the time of sampling, and the shallow bays and coastal waters and land areas could have had much higher concentrations of several of the tracer species. The observed relatively high values of $\mathrm{SO}_{2}$ may also have originated from surface anthropogenic sources in Japan. However, it is also to be noted that there were two active volcanoes in the area, Sakura-Jima $\left(31.58^{\circ} \mathrm{N}, 130.67^{\circ} \mathrm{E}, 1360-\mathrm{m}\right.$ elevation) and Unzen $\left(32.75^{\circ} \mathrm{N}, 130.03^{\circ} \mathrm{E}, 1118-\mathrm{m}\right.$ elevation), and as may be seen from Plate 2, air from their vicinity could easily have been entrained into the eye region.

Aerosol values (Figure 4f) show two ranges near the eye: $5-10$ particles $\mathrm{cm}^{-3}$ from 0457 to $0518 \mathrm{UT}$ and $15-35$ particles $\mathrm{cm}^{-3}$ until the end of the flight. As for the hydrocarbons, these aerosols may have originated from the continent.

\section{Upper Troposphere Outflow Region Ahead of Mireille}

Wind velocities in this region are shown in Figure $3 \mathrm{c}$ and temperature, $\mathrm{H}_{2} \mathrm{O}, \mathrm{DMS}$, and $\mathrm{O}_{3}$ in Figures 11-14. The closeness of the two legs to the southeast and northwest (0550-0635 UT) enables a vertical lapse rate to be found as $7.4^{\circ} \mathrm{C} \mathrm{km}^{-1}$ at $0610 \mathrm{UT}\left(-48.5^{\circ} \mathrm{C}\right.$ at $11.95 \mathrm{~km}$ versus $-39.5^{\circ} \mathrm{C}$ at $10.73 \mathrm{~km}$ ). High water vapor mixing ratios are encountered between the eye and $34^{\circ} \mathrm{N}, 131^{\circ} \mathrm{E}$ (Figure 12), and these correspond to intense clouds on the GMS image (Plate 1). DMS declines after passage through this cloudy, moist region (Figure 13), again suggesting that the active convection is bringing up material from the boundary layer that has been processed by passage through the typhoon system. What is termed outflow is therefore a mixture of air that has been advected into the typhoon area in the upper troposphere and air which has passed through the rising motion region of the typhoon. An aerosol sample from 0540 to $0638 \mathrm{UT}$ gave a ${ }^{7} \mathrm{Be}$ value of 63 fCi m ${ }^{-3}$, which compares with $46 \mathrm{fCi} \mathrm{m}^{-3}$ in the boundary layer, and therefore gives further evidence for this point. The ozone values along the sortie to the southeast show a general decrease with altitude (Figure 14), whereas carbon monoxide shows little change (Figure 4a).

\section{Air Mass Sources From Meteorological Data}

Three approaches can be used to examine possible sources: trajectory analysis, streamline analysis, and consideration of the rotational and irrotational components of the wind. In trajectory analysis, one tries to follow the motion of an individual parcel of air; the procedure, assumptions, caveats, and applications to PEM-West A case studies are given by $M$ errill [this issue]. The problem with application of trajectory analysis techniques to a typhoon case is that large vertical displacements occur in regions of strong convection, which invalidate the assumption that motion follows an isentropic surface at the large scale. Other problems arise because machine analyses often lack the fidelity necessary to reproduce reality [cf. Danielsen, 1974], and they are based on an 


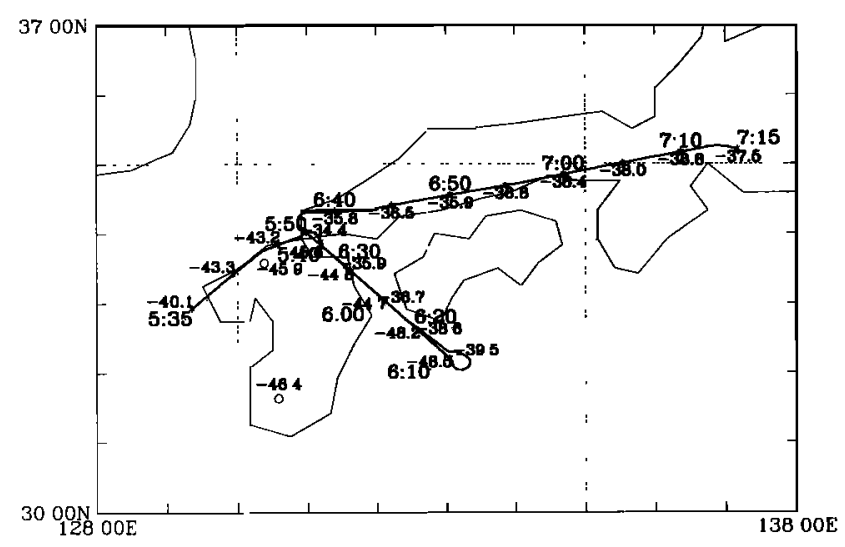

Figure 11. Map of DC-8 air temperature in the outflow region on September 27, 1991. Circles are radiosonde temperatures at $195 \mathrm{hPa}$. Time interval between data points is $5 \mathrm{~min}$. Units, degrees Celsius.

observational network that cannot catch the spatial variations at the typhoon scale. Streamline analysis too is limited by the horizontal spacing between radiosondes that go into it, but streamline analysis can be used qualitatively to identify the broad-scale air masses in the region. Streamlines and wind vectors are shown in Figure 15 for a level of $1000 \mathrm{hPa}$ based on grid point data supplied by the European Centre for Medium-Range Weather Forecasts (ECMWF). There is convergence of a marine air mass from the east and a continental air mass from the west in the vicinity of $130^{\circ} \mathrm{E}$. Streamlines have been used to characterize tropical storms in the southern hemisphere and give patterns which are almost a mirror image of Figure 15 [Holland, 1984]. The DC-8 sampling of the boundary layer at about $27^{\circ} \mathrm{N}, 136^{\circ} \mathrm{E}$ was made in the marine air. According to the trace constituent measurements reported in section 2, this air is clean and aged.

To estimate the overall mass flux in the typhoon region, the ECMWF wind velocities were decomposed into two components: an irrotational part which has no curl and a rotational part which has no divergence. While the first is usually smaller than the second, it is the most important for the mass flux through the system. These parts may be written in terms of a velocity potential $\chi$ and a stream function $\psi$ :

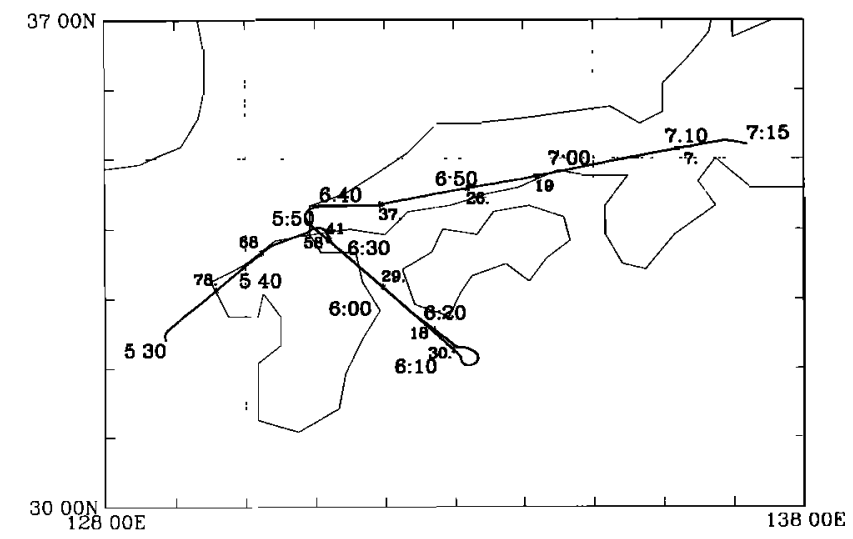

Figure 13. Map of DMS in the outflow region at about $11.2 \mathrm{~km}$ on September 27, 1991. Time interval between data points is $\mathbf{5 m i n}$. Units, parts per trillion by volume.

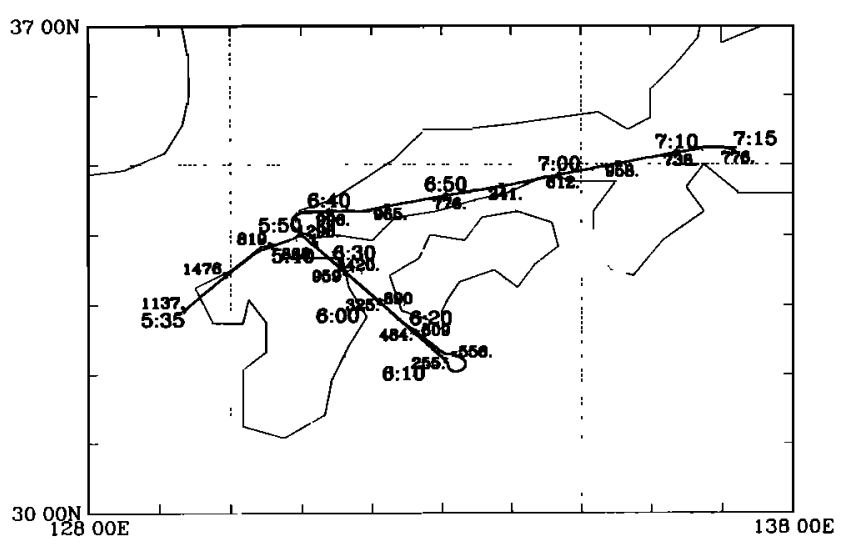

Figure 12. Map of DC-8 water vapor mixing ratio in the outflow region at about $11.2 \mathrm{~km}$ on September 27, 1991. Time interval between data points is $5 \mathrm{~min}$. Units, parts per million by volume.

$$
\underline{\sim}=v_{i r}+v_{\tau}=-\nabla \chi+\underset{\sim}{k} \times \nabla \psi
$$

Taking the divergence and curl in turn yields

$$
\begin{aligned}
& \nabla \cdot \underset{\sim}{v}=-\nabla^{2} \chi \\
& \text { curl } \underset{\sim}{v}=\nabla^{2} \psi
\end{aligned}
$$

From the observed or analyzed wind field, $\chi$ and $\psi$ may be obtained by solution of the Laplacians involved, and thence, $v_{\text {ir }}$ and $v_{r}$ may be found. It was fortunate that the ECMWF analysis was changed on September 17, 1991, 10 days before the DC-8 mission to Typhoon Mireille, to a higher resolution, T213, which gives the smallest wavelength resolved at the equator to be $190 \mathrm{~km}$. While this analysis cannot resolve the eye region, it is sufficient so that estimates of the irrotational flow over the large area covered by the typhoon may be made; it is this larger-scale flow that represents the response to the rising motion in the eye wall region. Examples of the divergent flow components are given in Figures 16 and 17 for 1000 and $700 \mathrm{hPa}$. There is a significant drift inward toward the center of up to $\sim 8 \mathrm{~ms}^{-1}$, and Mireille clearly dominates this

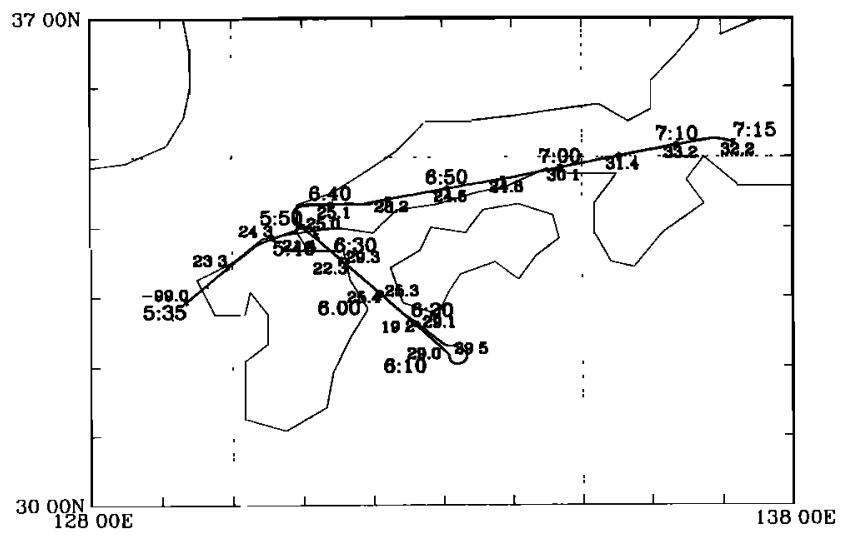

Figure 14. Map of ozone in the outflow region at about $11.2 \mathrm{~km}$ on September 27, 1991. Time interval between data points is $\mathbf{5 m i n}$. Units, parts per billion by volume. 


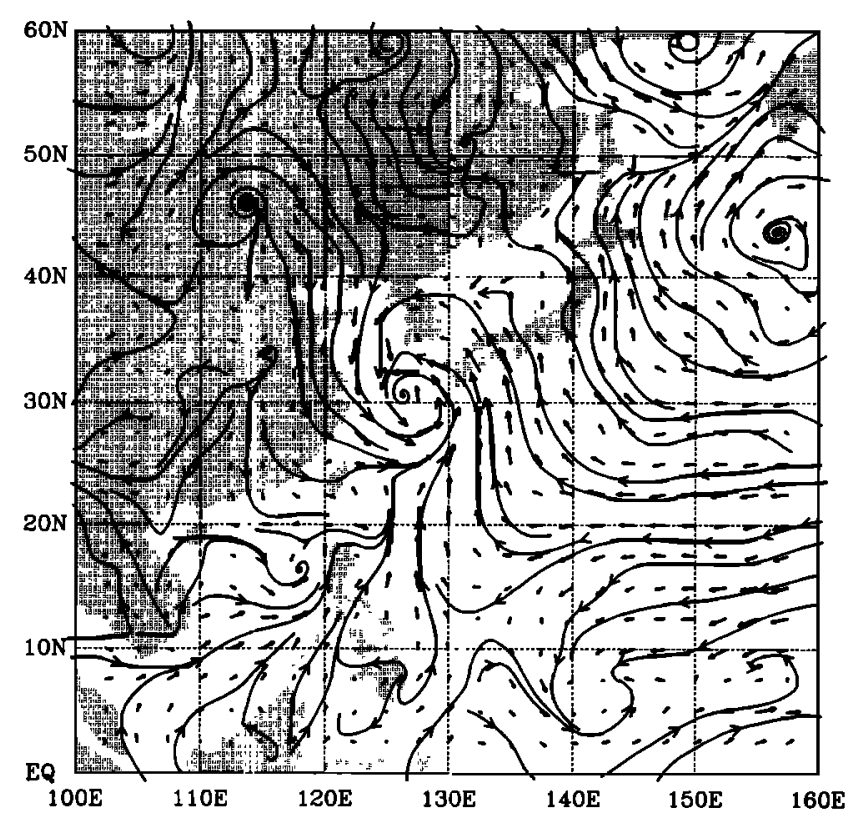

Figure 15. Streamlines and wind vectors for $0000 \mathrm{UT}$, September 27, 1991, based on ECMWF analysis for 1000 $\mathrm{hPa}$. Units, meters per second. Maximum vector (near eye) is 21 meters per second.

component of the flow over a large area $\left(\sim 110^{\circ}-150^{\circ} \mathrm{E}\right.$ at $\left.30^{\circ} \mathrm{N}\right)$. At $700 \mathrm{hPa}$ it appears that a substantial fraction of air near the typhoon-influenced region has originated from the continent; more air enters from the west than from the east, whereas at $1000 \mathrm{hPa}$, contributions from east and west are almost the same. By $300 \mathrm{hPa}$ (not shown) there is a divergent region in and ahead of the typhoon-influenced region; the streamlines show a trough approaching the

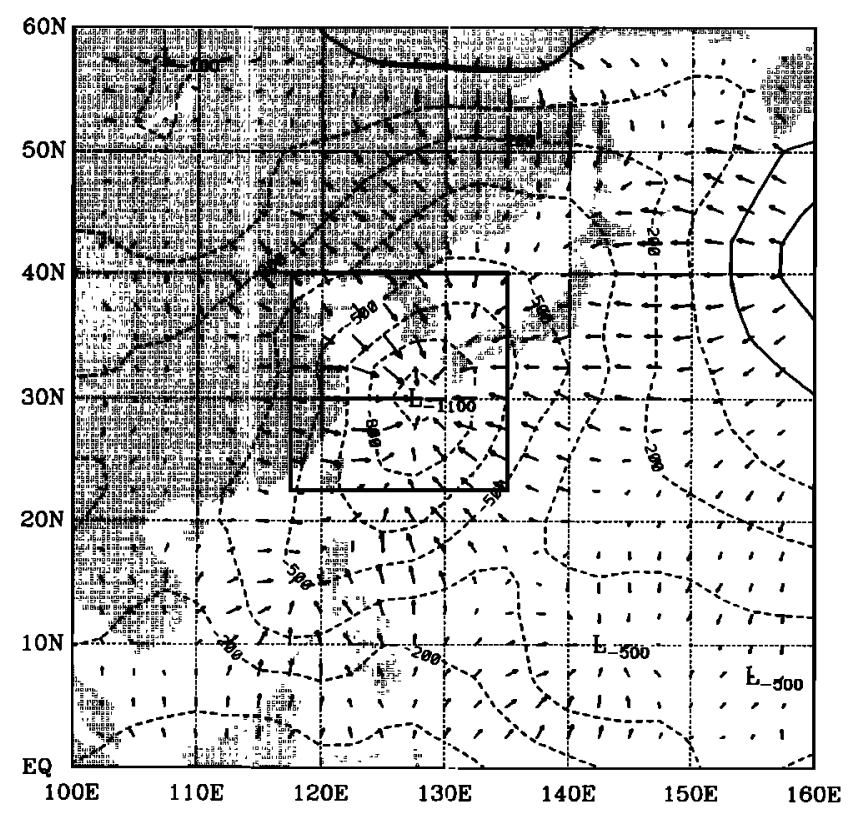

Figure 16. Velocity potential and divergent wind component at $1000 \mathrm{hPa}$ for $0000 \mathrm{UT}$, September 27, 1991. Wind vectors in meters per second. Velocity potential in $10^{4} \mathrm{~m}^{2} \mathrm{~s}^{-1}$. Maximum vector (near eye) is 9 meters per second.

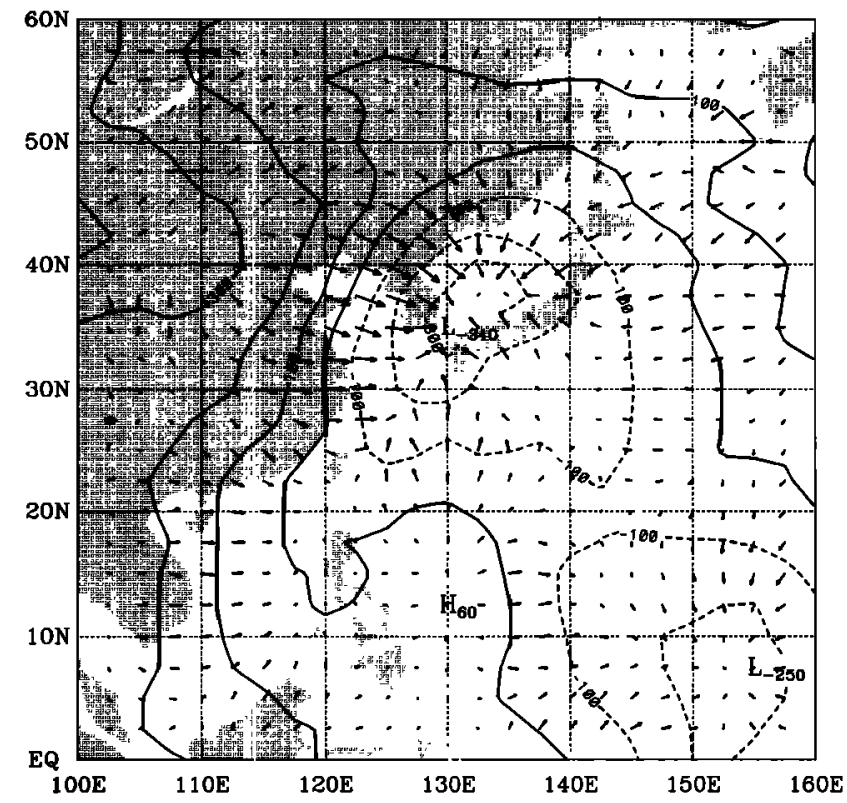

Figure 17. Velocity potential and divergent wind component at $700 \mathrm{hPa}$ for $0000 \mathrm{UT}$, September 27, 1991. Wind vectors in meters per second. Velocity potential in $10^{4} \mathrm{~m}^{2} \mathrm{~s}^{-1}$. Maximum vector (near eye) is 6 meters per second.

Asian coast from the west. The overall picture is that the typhoon boundary layer from a very large area is convergent into the central region, rises in the cloud systems surrounding the eye, and then moves out from the eye region aloft. Trace gases in the boundary layer are thus redistributed into the upper troposphere; the magnitude of this process will be examined further below. In addition, there is substantial inflow in the middle levels, much of it from the continent. From the cloud pattem and the higher temperatures in the eye it is clear that subsidence occurs there in the upper troposphere [cf. Willoughby, 1988], but the total mass involved would

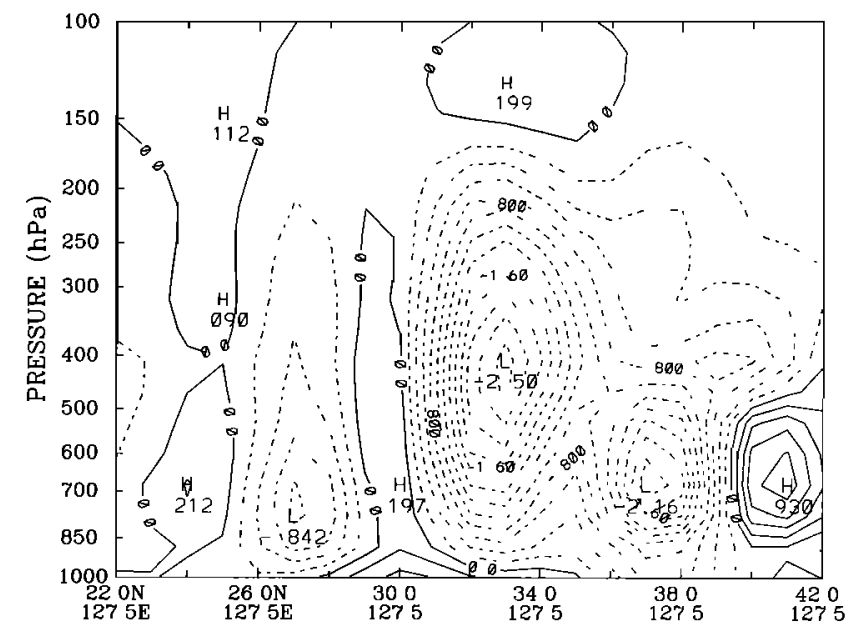

Figure 18. Cross section of vertical motion through Mireille (located at about $30^{\circ} \mathrm{N}, 127.5^{\circ} \mathrm{E}$ ) from ECMWF analysis at 0000 UT, September 27, 1991 based on divergent wind calculated from ECMWF data. Units, Pascals per second. Contour interval is $\mathbf{0 . 2}$. 

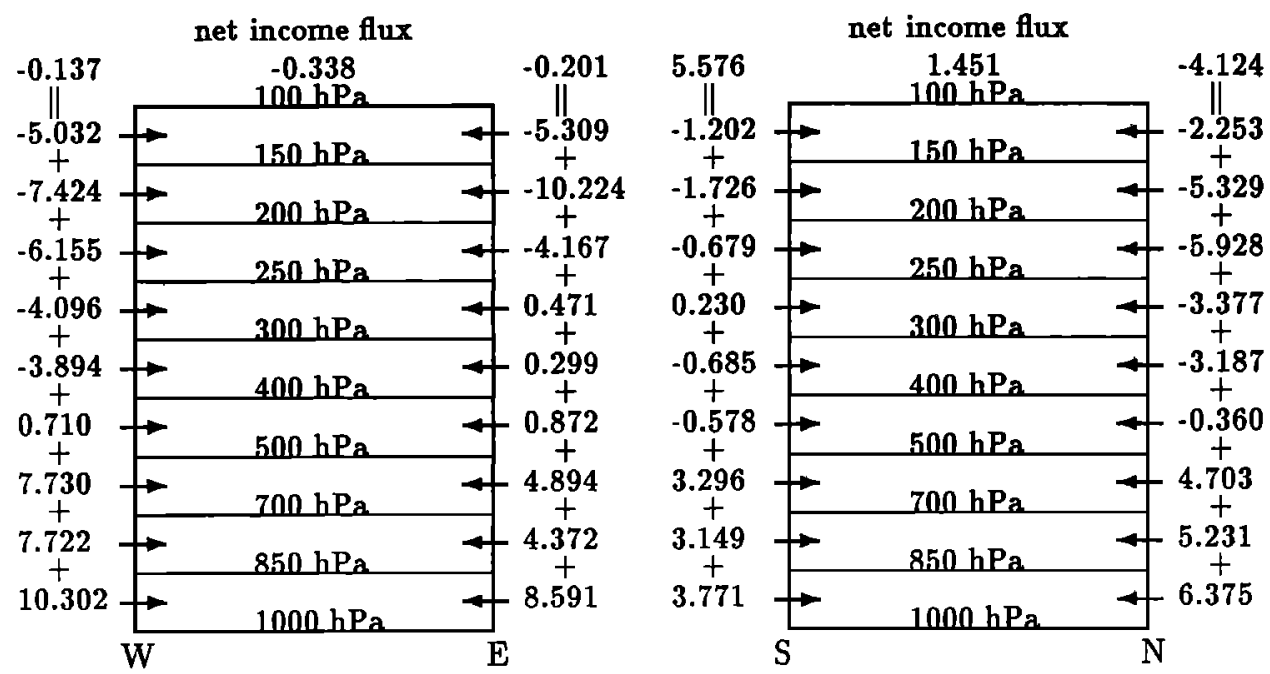

Figure 19. Example of mass flux components across the walls of the box in Figure 16 for September 27,1991 , based on divergent wind calculated from ECMWF data. Units, $10^{9} \mathrm{~kg} \mathrm{~s}^{-1}$.

appear to be only a small fraction of that carried upward in the cloud regions. In an effort to estimate the vertical motion in central core, it is assumed that the heat balance within the core is between adiabatic compression and radiative cooling. The relationship is

$$
\omega\left(\frac{\partial T}{\partial p}-\frac{R \bar{T}}{\mathrm{pC}_{p}}\right)=\frac{Q}{C_{p}} \equiv w\left[\Gamma_{d}-\Gamma\right]
$$

where $\Gamma_{\mathrm{d}}$ is the dry adiabatic lapse rate $\left(=\mathrm{g} / \mathrm{C}_{\mathrm{p}}\right.$, about $10^{\circ} \mathrm{C} \mathrm{km}^{-1}$ ) and $\Gamma=-\partial \mathrm{T} / \partial \mathrm{z}$. Q was calculated from the nearest radiosonde to the eye with good data. Station 47807 at $33.5^{\circ} \mathrm{N}, 130.4^{\circ} \mathrm{E}$ at $0600 \mathrm{UT}$ was used. To simulate conditions in the eye, air temperature was increased by $6^{\circ} \mathrm{C}$ at $250 \mathrm{hPa}$ between the environment and the eye, tapering to $1^{\circ} \mathrm{C}$ at $100 \mathrm{hPa}$ and $3^{\circ} \mathrm{C}$ at $700 \mathrm{hPa}$. Specific humidity was taken directly from the sounding. Cooling rates calculated for the upper troposphere were about $3.3^{\circ} \mathrm{C} \mathrm{d}^{-1}$. The local lapse rate was $7.7^{\circ} \mathrm{C} \mathrm{km}^{-1}$. The value for $\mathrm{w}$ was thus $-1.7 \mathrm{~cm} \mathrm{~s}^{-1}$, a small subsidence.

Table 2. Mass Flux From Lower to Upper Troposphere

\begin{tabular}{lcc}
\hline & Flux per Unit Area \\
1991 & $10^{-3} \mathrm{~kg} \mathrm{~m}^{-2} \mathrm{~s}^{-1}$ & $\begin{array}{c}\text { Total Flux } \\
10^{9} \mathrm{~kg} \mathrm{~s}^{-1}\end{array}$ \\
\hline \multicolumn{3}{c}{ Supertyphoon Mireille } \\
September 24 & 5 & 20 \\
September 25 & 6 & 21 \\
September 26 & 6 & 27 \\
September 27 & 9 & 29 \\
September 28 & 5 & 19 \\
September 29 & 3 & 13 \\
& & \\
& & \\
October 5 & 3 & 14 \\
October 6 & 4 & 17 \\
October 7 & 5 & 20 \\
October 8 & 5 & 18 \\
October 9 & 4 & 16 \\
October 10 & 5 & \\
\hline
\end{tabular}

The ECMWF cross section of vertical motion through the storm (Figure 18) is not inconsistent with these low values. In fact, the subsidence in the eye is rather limited, and the cylindrical volume shown could be regarded as a Taylor column, as outlined further below. These conclusions do not agree with the relatively large sinking motion at $5 \mathrm{~km}$ in the core suggested by Willoughby [1988].

\section{Large-Scale Mass Flux}

A $171 / 2^{\circ} \times 171 / 2^{\circ}$ latitude-longitude box was drawn surrounding the typhoon (Figure 16), and flow into and out of the box was evaluated each day from the divergent wind component. An example appears in Figure 19 where it is evident that the majority of the inflow occurs below 500 $\mathrm{hPa}$. We are interested here in the mass flux passing between the boundary layer and the free troposphere and have therefore calculated the vertical flux through $850 \mathrm{hPa}$. Values in Table 2 show that Mireille was sampled on the day of maximum mass flux, $29 \times 10^{9} \mathrm{~kg} \mathrm{~s}^{-1}$. These values are compared with Typhoon Orchid sampled on October 8 , in Table 2; Mireille has about double the flux by Orchid but clearly a larger sample needs to be studied and compared with the flux by middle-latitude cyclones before the overall significance of these values from Mireille can be assessed. It would also be valuable to make an estimate of the actual area involved in the rising motion, perhaps by using weather radar. It is also worth noting from Figure 19 that as well as the boundary layer, the next two layers above also contribute substantially to the mass flux through the system. For example, the $700-$ to $500-\mathrm{hPa}$ layer contributes about $20 \times 10^{9} \mathrm{~kg} \mathrm{~s}^{-1}$ with at least one third of this material coming in from the adjacent Asian continent to the west, as may be seen from Figure 17.

Is the typhoon important in the general circulation in carrying trace constituents into the upper troposphere? This question is examined below for the case of DMS.

The PEM-West missions showed that DMS only reached the free troposphere from the boundary layer on three occasions: on September 16 over the North Pacific on a day of very strong convection as seen from the cloud videos; on September 27 in association with typhoon Mireille; and on October 8 in association with typhoon 


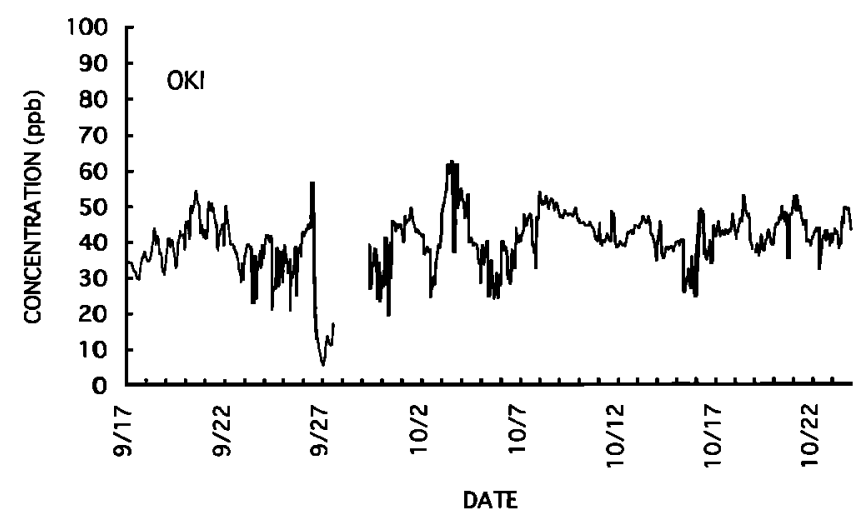

Figure 20a. Surface ozone variation at Oki Island $\left(36.3^{\circ} \mathrm{N}, 133.2^{\circ} \mathrm{E}\right)$ in the period September 17 to October 23, 1991 (provided by H. Akimoto). Units, parts per billion by volume.

Orchid (Table 3). For typhoon Mireille the mass of sulphur carried as DMS to the free troposphere from the boundary layer can be estimated from the values for total mass flux derived above in conjunction with the mass mixing ratio of DMS. The molecular weight of DMS is 62 , and the conversion to equivalent mass of sulphur from volume mixing ratio of DMS is therefore (ppv) $\times(62 / 28.9)$ $x(32 / 62)=1.11$. For a boundary layer mixing ratio of 80 pptv and a mass flux from Table 1 of $9 \times 10^{-3} \mathrm{~kg} \mathrm{~m}^{-2} \mathrm{~s}^{-1}$, the flux of sulphur to the free troposphere is $80 \times 1.11 \mathrm{x}$ $10^{-12} \times 9 \times 10^{-3} \mathrm{~kg} \mathrm{~S} \mathrm{~m}^{-2} \mathrm{~s}^{-1}$, or $69 \mu \mathrm{g} \mathrm{S} \mathrm{m}^{-2} \mathrm{~d}^{-1}$. This compares with recent estimates of surface oceanic DMS sulphur flux which have yielded $96 \mu \mathrm{g} \mathrm{m}^{-2} \mathrm{~d}^{-1}$ at $30^{\circ} \mathrm{N}$ in the central Pacific [Quinn et al., 1990], 227 $\mu \mathrm{g} \mathrm{S} \mathrm{m}^{-2} \mathrm{~d}^{-1}$ in the equatorial Pacific [Bates et al., 1993], and $27 \mu \mathrm{g} \mathrm{S} \mathrm{m}^{-2}$ $\mathrm{d}^{-1}$ in the Northeast Pacific [Bates et al., 1994]. Typhoon Mireille therefore generated a DMS sulphur flux into the upper free troposphere comparable to that normally associated with the flux from the ocean into the boundary layer.

The use of machine analysis may underestimate the mass flux circulating through the typhoon system, as the radiosonde wind fields may be smoothed excessively. There are relatively few estimates of the mass flux in the literature. McBride [1981] used about 800 rawinsondes to make a composite of Pacific typhoons and computed cunve-gence from the surface to $350 \mathrm{hPa}$ as $28 \times 10^{-3} \mathrm{~kg}$ $\mathrm{m}^{-2} \mathrm{~s}^{-1}$ evaluated over an $8^{\circ}$ diameter circle, while our value from Figure 19 for the surface to $400 \mathrm{hPa}$ is 21 $x 10^{-3} \mathrm{~kg} \mathrm{~m}^{-2} \mathrm{~s}^{-1}$ evaluated over an area about 6 times as large.

\section{Small-Scale Features}

During the descent to the boundary layer at 0228 UT near $28^{\circ} \mathrm{N}, 136^{\circ} \mathrm{E}$ the aircraft measured the vertical profiles of ozone and water vapor shown in Figure 6. The layered structure between about 5 and $6 \mathrm{~km}$ shows that watervapor-rich air is associated with lower ozone than watervapor-poor air. These layers seem to be about $400 \mathrm{~m}$ thick; similar layers show in the lidar echoes near to the center of the eye (Plate 3b). They appear to provide evidence of air from the boundary layer folded into higher levels, probably by convective processes. It is noteworthy that for this to occur, there must be substantial instability; that is, $\partial \theta_{\mathrm{e}} / \partial \mathrm{z} \leq$ 0 . ( $\theta_{\mathrm{e}}$ is equivalent potential temperature and $\mathrm{z}$ is altitude.)

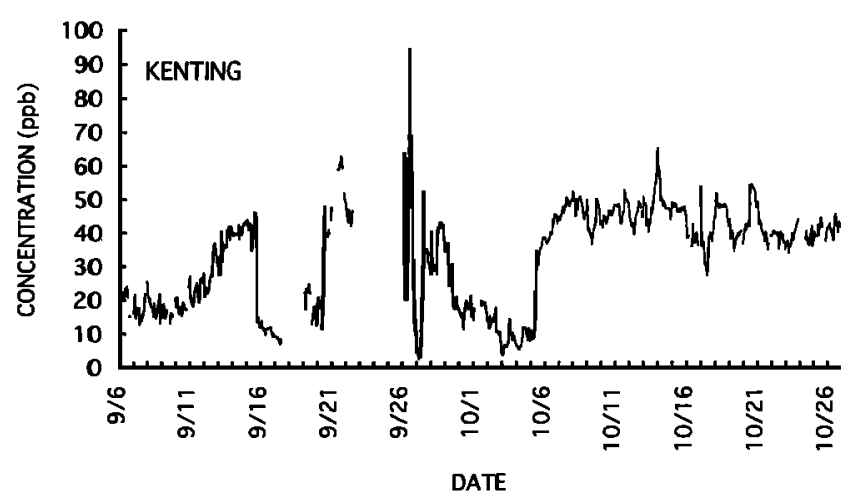

Figure 20b. Surface ozone variation at Kenting, Taiwan $\left(22^{\circ} \mathrm{N}, 120^{\circ} \mathrm{E}\right)$, in the period September 5 to October 3, 1991 (provided by C.M. Liu). Units, parts per billion by volume.

Where $\partial \theta_{\mathrm{e}} / \partial \mathrm{z}>0$ and the system is stable, the air spreads out horizontally, forming the layers noted. A summary of the properties of these layers is given elsewhere in this issue [Newell et al., this issue], where it can be seen that the characteristics of Figure 6 are fairly typical.

\section{Ozone From Surface Stations}

The only surface station sampling trace constituents which was close to the path of Mireille was Oki Island $\left(36.3^{\circ} \mathrm{N}, 133.2^{\circ} \mathrm{E}\right)$, which was in operation as part of the experiment "Perturbation by East Asian Continental Air Mass to Pacific Oceanic Troposphere" (PEACAMPOT). It is noteworthy that ozone mixing ratios as the eye passed over Oki at $\sim 1200$ UT were down to $5.5 \mathrm{ppbv}$ (Figure 20a). The station at Kenting, Taiwan $\left(22^{\circ} \mathrm{N}, 120.9^{\circ} \mathrm{E}\right)$ reported a value of about 3 ppbv on September 27 (Figure 20b), when the surface pressure in the Kenting area was about 1007 hPa. At 0600 UT on September 26, Mireille was about $550 \mathrm{~km}$ to the northeast of Kenting, and there was a trough

Table 3. Mixing Ratios of Dimethylsulfide (DMS) in the Boundary Layer and the Upper Troposphere

\begin{tabular}{rllr}
\hline Mission & \multicolumn{1}{c}{1991} & Boundary Layer & $>8 \mathrm{~km}$ \\
\hline 4 & September 16 & 320,260 & 0 \\
5 & September 18 & 170 & 90 \\
6 & September 22 & 30,40 & $3-6$ \\
7 & September 24 & 35,12 & 4 \\
8 & September 25 & $90,110,80$ & 2 \\
9 & September 27 & 95 & 80 \\
10 & October 1 & 120 & 2 \\
11 & October 2 & & \\
12 & October 4 & 11,8 & 2 \\
13 & October 6 & 45,48 & 2 \\
14 & October 8 & 34 & 45 \\
15 & October 12 & 65 & 5 \\
16 & October 13 & 30 & 2 \\
17 & October 15 & $22,27,30 / 38$ & 6 \\
18 & October 18 & 35 & 6 \\
19 & October 19 & 23 & 3 \\
20 & October 20 & 24,30 & 2 \\
\hline
\end{tabular}

Units: Parts Per Trillion by Volume 
in the direction of Kenting associated with the interplay that had been taking place between Typhoon Mireille and Typhoon Nat which had previously passed over Kenting. The low ozone values at Kenting (Figure 20b) may have been associated with air which had been brought up from the lower latitudes by the typhoons. Unfortunately, the station power was turned off during the passage of Typhoon Nat on September 23. In the case of Oki the transfer is more easily understood, as the eye passed over the station (see Figure 1). The low (5 ppbv) ozone values here are in general agreement with those reported by lidar in the tropospheric region of the eye (see Plate 3). We speculate that the eye region is a cylindrical sample of tropical air "packaged" by the circulation which has a continuity rather like that of a classical Taylor column. Taylor [1923] performed some experiments to check an analysis by Proudman [1916] which showed that all slow steady motions of a rotating liquid must be two dimensional. Taylor showed that when a sphere or cylinder is pulled across a rotating tank of water, it is accompanied by a cylinder of water above it having the same diameter. He did this by ejecting dye into the water above the sphere or cylinder and noting that it diverged around an imaginary cylinder above the sphere or cylinder. If dye was ejected into the imaginary cylinder, it stayed inside the cylinder and moved across the tank with it. It is this imaginary cylinder which is called a Taylor column. Yih [1977] reports that Taylor also experimented with fish in the tank, and they would try to avoid the cylinder as if sensing the presence of a solid obstacle. Low mixing ratios of tropical ozone found in both the laser images (Plate 3) and in the Oki surface station data (Figure 20a) are thought to correspond to the dye in the experiment. The equivalent potential temperature computed from the ECMWF data (Figure 21) shows neutral stability near the typhoon center, but again the limited horizontal resolution must be borne in mind.

\section{Total Ozone Relationships}

There have been several studies of the association between total ozone and tropical cyclones, including those in the western North Pacific. Some rather complex relationships were found which depended on whether the systems were intensifying or not intensifying [e.g., Stout and Rodgers, 1992]. We were provided with Total Ozone Measurements Satellite (TOMS) data each day in the field, and after the mission we obtained digital data. The maps for September 26-27 showed no special relationship between Mireille and total ozone in accord with the lidar and cirrus cross sections discussed earlier. These comments apply to the region we could measure directly. The question concerning stratosphere to troposphere exchange outside the eye cannot be examined experimentally with our measurements. However, it was noted that high potential vorticity (PV) values were indicated on the ECMWF $315 \mathrm{~K}$ analysis drawn up for this experiment.

\section{Possible Remote Sources}

A cross section along the Asian coast of the zonal flow (not shown; see Bachmeier et al. [this issue] for related data) illustrates that material may have entered the region from the west. This material could have reached the Asian west coast from Europe in a few days. Even allowing for meridional meandering and the fact that aircraft observations were not taken in the maximum velocity region gives a reasonable time of about 4 days, well within the $\mathrm{C}_{2} \mathrm{H}_{6}$ lifetime. It is clear that convection anywhere along the back trajectory could have introduced the material into the upper troposphere and that the vertical shear could have produced a vertical gradient of $\mathrm{C}_{2} \mathrm{H}_{6}$, such as was observed landing at Tokyo, where values at $7.5 \mathrm{~km}$ were about double those in the boundary layer.

\section{Photochemical Environment}

Although a detailed description of the photochemical environment of typhoon Mireille is not the main focus of this paper, for purposes of completeness the authors have summarized some of the general photochemical features of this system and have then contrasted these to air parcels sampled in the same geographical region under nontyphoon conditions. For example, in Figure 4d the observed mixing ratios for the photochemical products $\mathrm{H}_{2} \mathrm{O}_{2}$ and $\mathrm{CH}_{3} \mathrm{OOH}$ are reported as a time series, together with model-calculated profiles of the centrally important oxidizing species, the hydroxyl radical. If the midday time period of 0330 UT to 0540 UT is examined, it can be shown that the median level of $\mathrm{H}_{2} \mathrm{O}_{2}$ (based on 3-min averaged data) is $1032 \mathrm{pptv}$, whereas that for $\mathrm{CH}_{3} \mathrm{OOH}$ is considerably lower, being 193 pptv. Model-estimated OH concentrations for this same time period ranged from $1.6 \mathrm{x}$ $10^{6}$ to $8.1 \times 10^{6}$ molecules $\mathrm{cm}^{-3}$, giving a median value of $3.6 \times 10^{6}$ molecules $\mathrm{cm}^{-3}$. Some of the highest estimated $\mathrm{OH}$ values are seen for those times when the aircraft was approaching or passing through the eye wall region; it was at these times when highly elevated levels of NO were observed by the Georgia Tech instrument. By way of contrast to the typhoon environment, clear air observations over a similar altitude range and geographical location as typhoon Mireille gave midday median mixing ratios for $\mathrm{H}_{2} \mathrm{O}_{2}$ and $\mathrm{CH}_{3} \mathrm{OOH}$ of 412 and 125 pptv, respectively; and the average midday median $\mathrm{OH}$ level was estimated at 2.1 $x 10^{6}$ molecules $\mathrm{cm}^{-3}$. Thus one might tentatively conclude that the typhoon environment on average had an enhanced photochemical environment relative to the background upper troposphere. For further details on the photochemistry of this system, the reader is referred to other papers in this issue [e.g., Davis et al. and Heikes et al.].

\section{Conclusions}

As noted in the introduction, typhoons were sometimes thought to draw stratospheric air down into the upper troposphere. Ostlund [1968] found experimental evidence for such transfer from aircraft measurements of tritium which, like ozone, is higher in the stratosphere than in the troposphere. The DC-8 exploration of Mireille found no experimental evidence for this process in the lidar measurements of ozone; in fact, lidar measurements in the middle troposphere were very low. There was evidence, particularly from DMS, that boundary layer air was carried into the upper troposphere. The maximum vertical transport seems to occur in the wall cloud region; some of the DMS-rich air which reaches the upper troposphere moves into the eye and subsides, while the majority is in the divergent flow that spreads out in the upper troposphere. There is therefore a net transport of sulphur from the boundary layer to the upper free troposphere. Computations of the irrotational component of the flow suggest that the boundary layer from a large area is drawn 

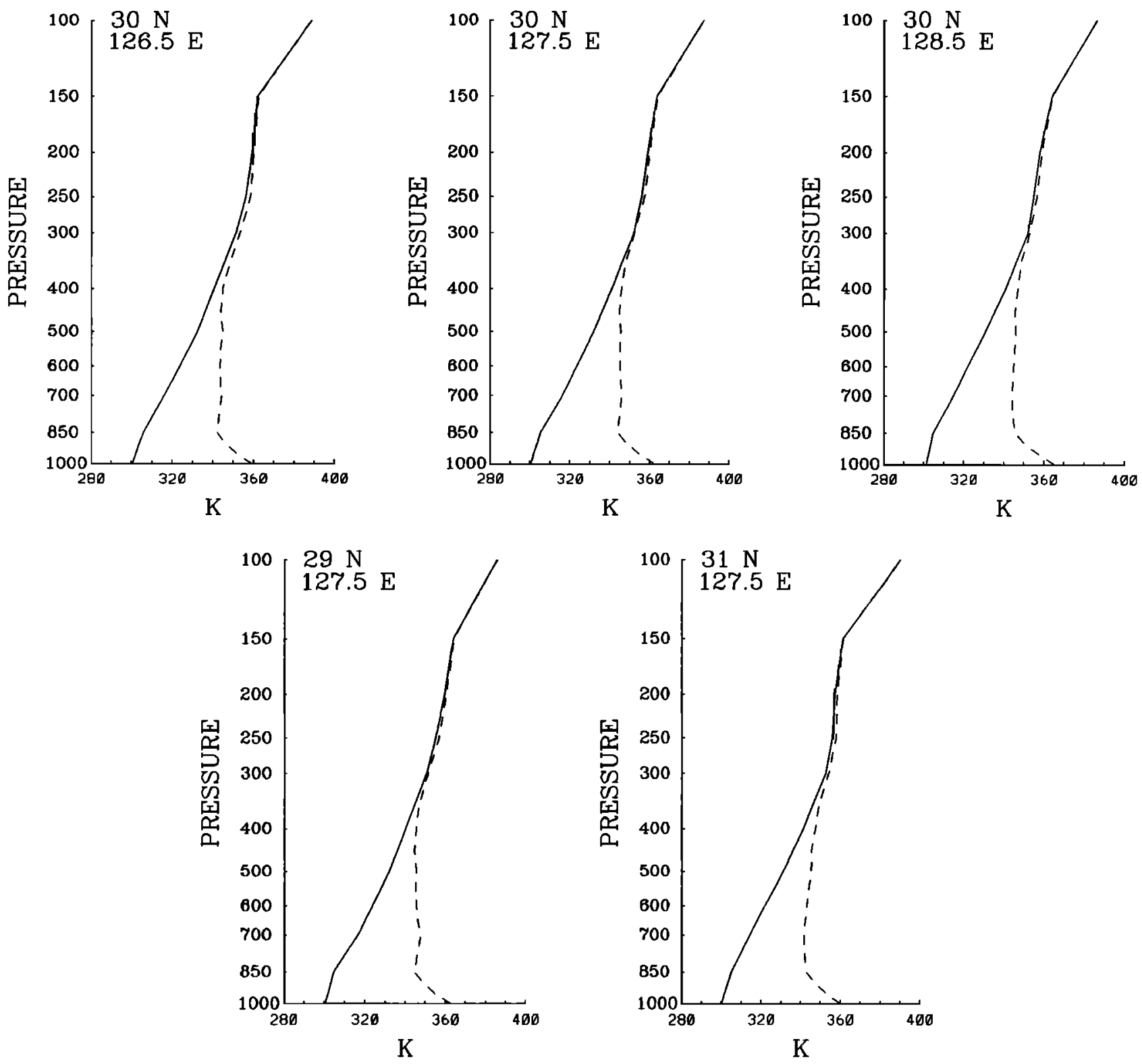

Figure 21. Potential temperature (solid lines) and equivalent potential temperature (dashed lines) for points near the eye center on September 27, 1995 at 0000 UT, based on ECMWF analysis.

into the central region. The mass flux from the boundary layer to the free troposphere by Mireille reaches $3 \times 10^{10}$ $\mathrm{kg} \mathrm{s}^{-1}$, peaking on the day the typhoon was sampled by the DC-8. This is about $50 \%$ greater than the flux from typhoon Orchid, which the DC-8 passed through on October 8, and almost triple the flux from an active cyclone in the North Pacific on September 6, 1991 (values not shown). The flux of sulphur as DMS transported into the upper free troposphere is approximately $69 \mu \mathrm{g} \mathrm{S} \mathrm{m}^{-2}$ $d^{-1}$, which is estimated to be nearly half the mean flux from the ocean into the boundary layer. To assess the importance of typhoons in the global sulphur budget, more samples are required and these, in turn, will need to be incorporated into a global model to form an assessment.

Boundary layer marine air was found to be low in the tracer species $\mathrm{O}_{3}, \mathrm{CO}, \mathrm{CS}_{2}, \mathrm{C}_{2} \mathrm{H}_{2}, \mathrm{C}_{2} \mathrm{H}_{6}, \mathrm{C}_{3} \mathrm{H}_{8}$, and $\mathrm{C}_{2} \mathrm{H}_{6}$, and rich in DMS. In the upper levels of the eye region and in the outflow region, $\mathrm{NMHCs}, \mathrm{O}_{3}$, and $\mathrm{CS}_{2}$ were found to be far more abundant, and modest increases in $\mathrm{CO}$ were also observed. These enhancements may have arisen if some of the air involved entered the system in the lower or middle troposphere from the continent. The trace gas NO was in some cases nearly 2 orders of magnitude higher than in the boundary layer, and there is evidence that one of the important sources of this NO was in situ production from lightning [see Davis et al., this issue]. The DMS appears to have originated from the marine boundary layer, although some of this may have entered the system from the coastal regions, as suggested by Plate 2 . The trace gas $\mathrm{SO}_{2}$ may have been entrained from the vicinity of Japan as a result of volcanic activity.

In sampling Typhoon Mireille, it is important to recognize that both continental and marine boundary layers were mixed together by the typhoon's circulation patterns. Thus in view of the fact that the continental boundary layer was not sampled directly, it is difficult to distinguish contributions from the continental boundary layer and the continental free troposphere. 
The low ozone in the eye region, shown by the lidar measurements and by Oki Island station, may have been transported directly from low latitudes in a process akin to a Taylor column. Low ozone values aloft would also fit with an ultimate low-latitude source for the air in the eye region. Ostlund (1968) also mentioned that some of his tritium results could be explained if the eye contained old air which had been trapped since the formation of the circulation. Finally, the NMHC data suggest the possibility that distant sources to the west may contribute to material found in the typhoon.

Acknowledgments. The work was supported under the NASA GTE program grant NAG-1-1252. We acknowledge help in the field with real-time trajectory analyses and afterward with data from ECMWF. The meteorological staff at Yokota Air Base kindly helped throughout the Mireille flight and provided analyzed synoptic maps afterward.

\section{References}

Bachmeier, A. S., R. E. Newell, M. C. Shipham, Y. Zhu, D. R. Blake, and E. V. Browell, PEM-West A meteorological overview, J. Geophys. Res., this issue.

Bates, T. S., K. C. Kelly, and J. E. Johnson, Concentrations and fluxes of dissolved biogenic gas (DMS, $\mathrm{CH}_{4}, \mathrm{CO}, \mathrm{CO}_{2}$ ) in the equatorial Pacific during the SAGA 3 experiment, $J$. Geophys. Res., 98, 16,969-16,977, 1993.

Bates, T. S., R. P. Kiene, G. V. Wolfe, P. A. Matrai, F. P. Chavez, K.R. Buck, B.W. Blomquist, and L. Cuhel, The cycling of sulphur in surface seawater of the Northeast Pacific, $J$. Geophys. Res., 99, 7835-7843, 1994.

Bergeron, T., Reviews of Modern Meteorology, 12, The problem of tropical hurricanes, Q. J. R. Meteorol. Soc., 80, 131-164, 1954.

Crosley, D. R., NOy Blue Ribbon panel, J. Geophys. Res., this issue.

Danielsen, E. F., Review of trajectory methods, $A d v$. Geophys., 18(B), 73-94, 1974.

Davis, D. D., et al., Assessment of ozone photochemistry in the western North Pacific as inferred from PEM-West A observations during fall 1991, J. Geophys. Res., this issue.

Gregory, G. L., A. S. Bachmeier, D. R. Blake, B. G. Heikes, D. C. Thornton, A. R. Bandy, J. D. Bradshaw, and Y. Kondo, Chemical signatures of aged Pacific marine air. Mixed layer and free troposphere as measured during PEM-West $A, J$. Geophys. Res., this issue.

Heikes, B. G., et al., Hydrogen peroxide and peroxide distributions related to ozone and odd hydrogen over the North Pacific in the fall of 1991, J. Geophys. Res., this issue.

Hoell, J. M., D. D. Davis, S. C. Liu, R. E. Newell, M. C. Shipham, H. Akimoto, R. J. McNeal, R. J. Bendura, and J. W. Drewry, Pacific Exploratory Mission-West A (PEM-West A): September-October, 1991, J. Geophys. Res., this issue.

Holland, G. J., On the climatology and structure of tropical cyclones in the Australian/southwest Pacific region, $I$, Data and tropical storms, Aust. Meteorol. Mag., 32, 10-15, 1984

McBride, J. L., Observational analysis of tropical cyclone formation, 1, Basic description of data sets, J. Atmos. Sci., 38, 1117-1131, 1981.

Merrill, J. T., Trajectory results and interpretation for PEM-West A, J. Geophys. Res., this issue.

Newell, R. E., et al., Vertical fine-scale atmospheric structure measured from the NASA DC-8 during PEM-West A, $J$. Geophys. Res., this issue.

Östlund, H. G ., Hurricane tritium, II, Air-sea exchange of water in Betsy 1965, Tellus, 20, 577-594, 1968.

Proudman, J., On the motion of solids in a liquid possessing vorticity, Proc. R. Soc. London, A, 100, 114-121, 1916.
Quinn, P. K., T. S. Bates, and J. E. Johnson, Interactions between the sulphur and the reduced nitrogen cycles over the central Pacific Ocean, J. Geophys. Res., 95, 16,405-16,416, 1990.

Rudolph, D. K., and C. P. Guard, 1991 Annual Tropical Cyclone Report, pp. 108-111, Joint Typhoon Waming Cent., COMNA VMARIANAS, Guam, Mariana Islands, 1992.

Singh, H. B., Reactive nitrogen in the troposphere, Environ. Sci. Technol., 21, 320-327, 1987.

Stout, J., and E. B. Rodgers, Nimbus-7 total ozone observations of westem North Pacific tropical cyclones, J. Appl. Meteorol., 31, 758-783, 1992.

Taylor, G. I., Experiments on the motion of solid bodies in rotating fluids, Proc. R. Soc. London, A, 104, 213-218, 1923.

Willoughby, H. E., The dynamics of the tropical cyclone core, Aust. Meteorol. Mag., 36, 183-191, 1988.

Yih, C. S., Fluid Mechanics, p. 82, West River Press, Ann Arbor, Mich., 1977.

H. Akimoto, University of Tokyo, 4-6-1 Komaba Meguro-ku, Tokyo 153 305, Japan. (e-mail: akimotothj@tansei.cc.utokyo.ac.jp)

B. E. Anderson, E. V. Browell, G. L. Gregory, G. W. Sachse and M. C. Shipham, NASA Langley Research Center, Hampton, VA 23681. (e-mail: b.e.anderson@larc.nasa.gov; e.v.browell@larc.nasa.gov; g.l.gregory@larc.nasa.gov; g.w.sachse@larc.nasa.gov; shipham@weatherman.larc.nasa.gov)

A. S. Bachmeier, Lockheed Engineering and Sciences, Co., Hampton, VA 23681. (e-mail: a.s.bachmeier@larc.nasa.gov)

A. R. Bandy and D. C. Thornton, Drexel University, Philadelphia, PA 19104. (e-mail: arb@acl.chemistry.drexel.edu; dct@ac2.chemistry.drexel.edu)

D. R. Blake and F. S. Rowland, University of California at Irvine, Irvine, CA 92717. (e-mail: dblake@orion.oac.uci.edu; rowland@uci.edu)

J. D. Bradshaw, J. H. Crawford, D. D. Davis and S T. Sandholm, Georgia Institute of Technology, Atlanta, GA 30332. (e-mail: jb57@prism.gatech.edu; crawford@montreal eas. gatech.edu; dd16@acme.gatech.edu; ss27@ prism.gatech.edu)

W. Brockett, L. DeGreef, D. Lewis, D. McCormick, and E. Monitz, Ames Science and Applications Aircraft Division, NASA Ames Research Center, Moffett Field, CA 94035.

J. E. Collins Jr., Science and Technology Corp., Hampton, VA 23681. (e-mail: j.e. collins@larc.nasa.gov)

J. E . Dibb and R. W. Talbot, University of New Hampshire, Durham, NH 03824. (e-mail: rwt@christa.unh.edu)

B. G. Heikes and J. T. Merrill, University of Rhode Island, Kingston, RI 02881. (e-mail: zagar@notos.gso.uri.edu; jmerrill@boreas.gso.uri.edu)

R. E. Newell (corresponding author), W. Hu, Z-X. Wu, and Y. Zhu, Massachusetts Institute of Technology, 54-1824, 77 Massachusetts Avenue, Cambridge, MA 02139. (e-mail: newell@newelll.mit.edu)

K. K. Kelly and S. C. Liu, NOAA Aeronomy Laboratory, R/E/AL-4, 325 Broadway, Boulder, CO 80303. (e-mail: liu@al.noaa.gov)

Y. Kondo and M. Koike, Nagoya University, Japan. (e-mail: kondo@stelab.nagoya-u.ac.jp; koike@stelab.nagoya-u.ac.jp)

C.-M. Liu, Department of Atmospheric Science, National Taiwan University, Taipei, Taiwan. (e-mail: liucm@ccms.ntu.edu.tw)

F. Sakamaki, National Institute for Environmental Studies, Tsukuba, Japan.

H. B. Singh, NASA Ames Research Center, Moffett Field, CA 94035. (e-mail: hanwant_singh@qmgate.arc.nasa.gov)

(Received June 23, 1994; revised March 11, 1995; accepted March 30, 1995.) 